\title{
Cytokinergic IgE action in mast cell activation
}

\section{Heather J. Bax, Anthony H. Keeble and Hannah J. Gould*}

Randall Division of Cell and Molecular Biophysics, King's College London, London, UK

\section{Edited by:}

Toshiaki Kawakami, La Jolla Institute for Allergy and Immunology, USA

Reviewed by:

Song Guo Zheng, University of Southern California, USA

Bridget S. Wilson, University of New Mexico, USA

Junji Yodoi, Kyoto University, Japan Yoshimichi Okayama, Nihon University

School of Medicine, Japan

*Correspondence:

Hannah J. Gould, Randall Division of Cell and Molecular Biophysics, King's College London, 3.6B New Hunt's House, Guy's Campus, London SE1 IUL, UK.

e-mail: hannah.gould@kcl.ac.uk
Some 10 years ago it emerged that at sufficiently high concentrations certain monoclonal mouse IgEs exert previously unsuspected effects on mast cells. Thus they can both promote survival and induce activation of mast cells without the requirement for antigens. This was a wake up call that appears to have been missed (or dismissed) by the majority of immunologists. The structural attributes responsible for the potency of the so-called "highly cytokinergic" or HC IgEs have not yet been determined, but the events that ensue when such IgEs bind to the high-affinity receptor, FceRI, on mast cells have been thoroughly studied, and are strikingly similar to those engendered by antigens when they form cross-linked complexes with the receptors. We review the evidence for the cytokinergic activity of IgE, and the structural features and known properties of immunoglobulins, and of IgE in particular, most likely to be implicated in the phenomenon. We suggest that IgEs with cytokinergic activity may be generated by local germinal center reactions in the target organs of allergy. We consider also the important implications that the existence of cytokinergic IgE may have for a fuller understanding of adaptive immunity and of the action of IgE in asthma and other diseases.

Keywords: allergy, asthma, conformational isomerism, cytokinergic, IgE, mast cell, SPE-7

\section{INTRODUCTION}

In the classical model for allergenic activation, a multivalent antigen - the allergen - enters the body and is captured by a pre-existing complex of an IgE antibody bound to its highaffinity receptor, FceRI, on the membrane of mast cells, and basophils. Cross-linking of the IgE-FceRI complex triggers mast cell activation and the release of substances that cause the symptoms of allergy (Figure 1A; Kinet, 1999). Allergic reactions occur within minutes of allergen exposure, differing thereby from other immune responses, which occur on a longer timescale. This is in part due to the unusually high-affinity of the IgE-FceRI interaction compared to those between other antibody isotypes and their receptors (Gould et al., 2003). Thus allergens bind to IgE-FceRI complexes formed on these cells in anticipation of exposure to allergen rather than to free IgE, followed by subsequent docking of this complex on unoccupied receptor sites. Only a minuscule proportion of the many receptor molecules on the mast cell membrane need be cross-linked for "immediate hypersensitivity" (MacGlashan, 2005). This mechanism, common to all allergic diseases including allergic asthma, can take place in any bodily tissues populated by IgE and mast cells, notably the respiratory tract, eyes, skin, and gastrointestinal tract, or in the circulation with basophils (systemic anaphylaxis).

Tissue targets are strategically located as barriers against the environment, and the sensitization of mast cells to antigens by antigen-specific IgE antibodies may be one of the many mechanisms, including those of both innate and adaptive immunity that have evolved to impede the entry of pathogens or toxins into the body and thus avert worse mayhem than that generally caused by mere allergic reactions (Galli et al., 1999, 2008; Palm et al., 2012). The central dogma of allergology is that allergen cross-linking of IgE-FceRI complexes on the mast cells is critical for IgE-mediated mast cell activation. The recent discovery that allergen is not required for certain IgEs to stimulate activities resembling those in the classical model challenges this dogma (Figure 1B). The designation "cytokinergic" is meant to specify both the IgEs displaying such activity and the type of activity itself (Kitaura et al., 2003). The nature of allergen-independent mast cell activation by cytokinergic IgE is unknown.

We review now the experimental evidence for cytokinergic $\operatorname{IgE}$ activity and the implications for IgE functions in health and disease. Previous reviews on cytokinergic IgE have focused on the similarities and differences in signal transduction in mast cells by allergens and cytokinergic IgE (Kawakami and Galli, 2002; Kawakami and Kitaura, 2005; Kashiwakura et al., 2011). Here we consider the possible structural determinants of cytokinergic activity in the IgE molecule itself, along with the possible origins and biological function of cytokinergic IgE.

\section{CYTOKINERGIC IgE ACTIVITIES EFFECTS ON FC\&RI EXPRESSION}

Two types of cells, blood basophils and mucosal and connective tissue mast cells, are responsible for the immediate hypersensitivity reactions that are the most striking characteristic of the allergic response. Both cell types are generated in the bone marrow, but the latter migrate to the tissues, where they differentiate into mature mast cells expressing the high-affinity IgE receptor, FceRI (Kitamura and Ito, 2005). This receptor comprises four subunits, one $\alpha$ chain, containing the IgE binding site in its extracellular sequence, one $\beta$-chain and two $\gamma$-chains, which are involved in synergistic signal transduction (Kinet, 1999; Turner and Kinet, 1999). Some 35 years ago two groups discovered a positive correlation between FceRI levels on human basophils and the concentrations of $\operatorname{IgE}$ in the serum (Conroy et al., 1977; Stallman and Aalberse, 1977). 

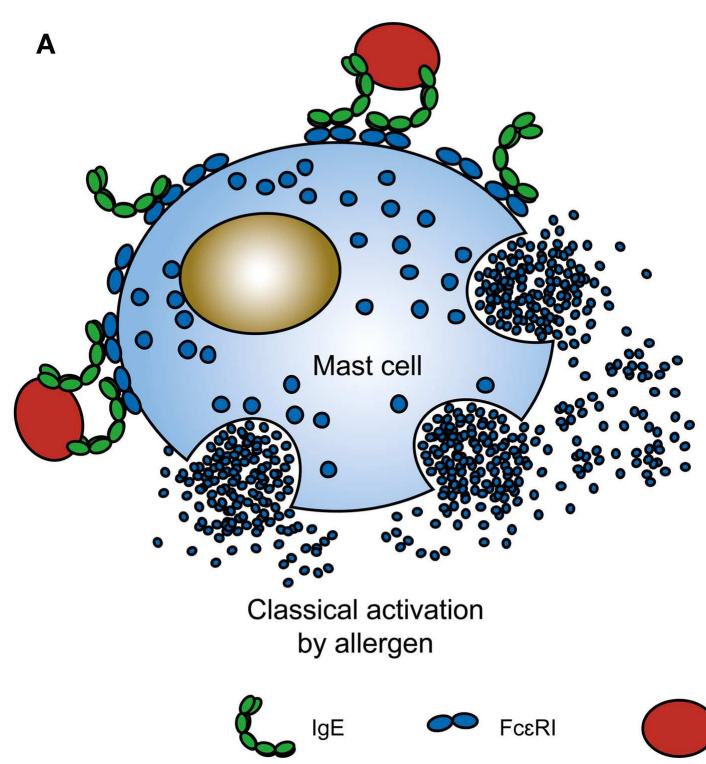

FIGURE 1 | Comparison between classical allergen and cytokinergic IgE activation of mast cells. (A) In the classical allergic response, multivalent allergens cross-link IgE-Fc\&RI complexes on the surface of mast cells to trigger mast cell activation, e.g., mast cell degranulation. (B) In contrast, the binding

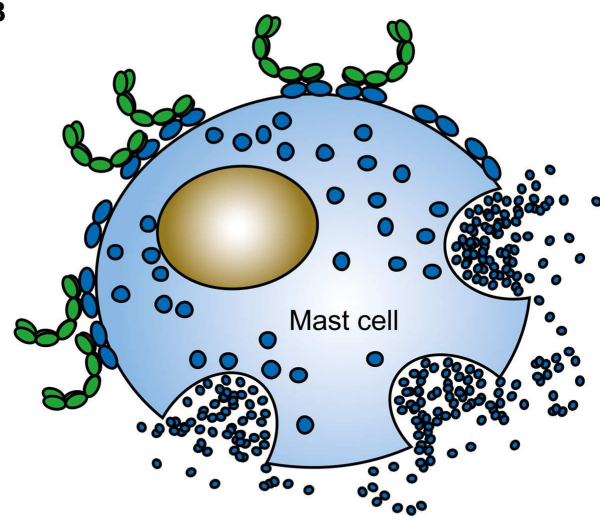

Activation by cytokinergic lgE

Allergen $\quad 8 \AA_{\circ}^{\circ}$ Pro-inflammatory mediators

of highly cytokinergic $(\mathrm{HC}) \lg E$ to $F c \varepsilon R I$ activates mast cells in the absence of antigen. Cytoplasmic $\alpha$, and the $\beta$ and $\gamma$ chains of $F_{c \varepsilon} R$ have been omitted for simplicity. See Figure $\mathbf{3}$ and Section

"Mechanisms of Cytokinergic Activity" for possible mechanisms for cytokinergic lgE cross-linking of F $\mathrm{c \varepsilon R}$ R complexes.
Several other groups later reached the same conclusion in studies on mast cells (Furuichi et al., 1985; Hsu and MacGlashan, 1996; Yamaguchi et al., 1997). Notably, these experiments required IgE concentrations some 100 times higher (e.g., $>1.5 \mu \mathrm{g} / \mathrm{ml}$; Furuichi et al., 1985) than those that typically suffice for allergen sensitization of mast cells. In vitro experiments revealed that the up-regulation of FcERI is due to the inhibition of endocytosis and under certain circumstances also de novo protein synthesis (Yamaguchi et al., 1997). Up-regulation of FceRI by IgE enhances the IgE-dependent functions of mouse and human mast cells (Galli et al., 1999; MacGlashan, 2005). The effects of IgE binding to FceRI on a wide range of other cells - antigen-presenting cells such as Langerhans cells, dendritic cells and monocytes, epithelial cells, and muscle cells, all expressing a form of the receptor devoid of the $\beta$-chain - are less well documented. That there are other facets of the cytokinergic activity of IgE yet to be explored is suggested by the existence of two other IgE receptors, CD23 and galectin-3 (Liu, 2005), and membrane IgE (the B cell receptor) on IgE-expressing B cells (see Cytokinergic Activity of IgE Via FceRI in Other Cells or Mediated by Other IgE Receptors).

\section{EFFECTS ON MAST CELL SURVIVAL}

The incubation of mouse bone-marrow-derived cultured mast cells (BMMC) with certain hybridoma IgEs has the striking effect of increasing cell survival after removal of growth factors (Asai et al., 2001; Kalesnikoff et al., 2001). Implication of IgE binding to FceRI in this effect was inferred because it was not stimulated by IgG or in BMMC from an $\mathrm{Fc} \varepsilon \mathrm{RI}^{-/-}$knockout mouse. BMMC from mouse mutants were also used to exclude any possible cytokinergic activity mediated by alternative IgE receptors, CD23, or galectin-3. Asai et al. (2001) demonstrated that IgE acted by inhibiting apoptosis, rather than stimulating DNA synthesis, while Kalesnikoff et al. (2001) observed up-regulation of Bcl- $\mathrm{X}_{\mathrm{L}}$, a known anti-apoptotic protein, which may account for this.

These authors noted that the threshold concentration of $\operatorname{IgE}$ for stimulation of mast cell survival, as previously found for upregulation of FcERI, was several orders of magnitude higher than required for allergen sensitization (Asai et al., 2001; Kalesnikoff et al., 2001). Asai et al. (2001) also observed that washing away the unbound IgE after maximum up-regulation of FceRI caused an immediate loss of the survival effect, notwithstanding the persistence of the IgE-FceRI complexes available for antigen activation. We will return to the implications of this observation later (see Is Cytokinergic IgE Activity an Artifact of Adventitious IgE Aggregation? and Dimensional Reduction and Orientation may Drive Self-Association of FceRI-Bound IgE). Further details relating to IgE regulation of mast cell survival can be found in several reviews (Kawakami and Galli, 2002; Kawakami and Kitaura, 2005; Kashiwakura et al., 2011).

\section{EFFECTS ON MAST CELL ACTIVATION}

Both publications discussed in the previous section show the results of additional assays of $\operatorname{IgE}$ stimulation of cytokine and leukotriene synthesis and secretion and cell degranulation (Asai et al., 2001; Kalesnikoff et al., 2001). Neither group detected leukotriene or histamine release, although these activities were seen in later studies with one of the IgEs, the DNP hapten-specific SPE-7 IgE used by Kalesnikoff et al. (2001). Remarkably, SPE-7 IgE alone stimulated interleukin (IL)-6, TNF- $\alpha$, IL-4 and IL-13 mRNA, and protein synthesis to a greater extent than antigen (DNP conjugated to human serum albumin; DNP-HSA) binding to the receptor-bound SPE-7. There were significant differences in the 
kinetics of the response to SPE-7 IgE in the presence and absence of antigen. For example, the IL- 6 mRNA and protein expression were delayed and then more prolonged in the absence of antigen. This was also the case for various downstream effects of the IgEs, including phosphorylation of the mitogen-activated kinases, ERK $1 / 2$, p38 and JNK, and the survival-enhancing kinase, PKB. The authors concluded that the cytokines must act in an autocrine or paracrine manner to increase cell survival. Extrapolating to the in vivo situation, they pointed out that the cytokines would also act on cell populations other than mast cells to enhance allergic (or cytokinergic) inflammation by, for example, inducing B cells to make more IgE by a positive feedback mechanism (Figure 2). It was not then clear why Asai et al. (2001) failed to observe cytokine secretion or stimulation of signal transduction in their experiments.

\section{HETEROGENEITY OF IgES}

This discrepancy in the results was soon resolved by comparing the IgEs used in these experiments (Kitaura et al., 2003). Of the eight different hybridoma IgEs examined by Kalesnikoff et al. (2001), three (including SPE-7 IgE) were found to be more "potent" (i.e., cytokinergic) than the other five. In a later survey of several DNPspecific monoclonal IgEs, namely H1 DNP- $\varepsilon-206, \mathrm{H} 1 \mathrm{DNP}-\varepsilon-26$ (Liu et al., 1980), and SPE-7 (Eshhar et al., 1980), three commercially available TNP-specific IgEs, IgE-3, C48-2 and C38-2, and an anti-dansyl IgE, 27-34, Kitaura et al. (2003) observed a wide spectrum of effects on mast cell survival and activation. They reproduced their earlier results with the anti-DNP H1 DNP- $\varepsilon$ 206 IgE (Asai et al., 2001), which again failed to stimulate cytokine production, and the results of Kalesnikoff et al. (2001) with SPE-7, which not only stimulated IL-6 production, but also led to synthesis/secretion of leukotrienes, histamine release, internalization of IgE, and DNA synthesis. They ranked the IgEs from highly (HC) to poorly cytokinergic (PC) in the order SPE-7 > H1 DNP$\varepsilon-26>\mathrm{H} 1 \mathrm{DNP}-\varepsilon-206$, according to their various activities and threshold concentrations for these activities. The activity of SPE$7 \mathrm{IgE}$ in stimulating histamine release from BMMC approached that of the same IgE at much lower optimal concentrations, nor was it further increased by the antigen. By contrast, the activity of

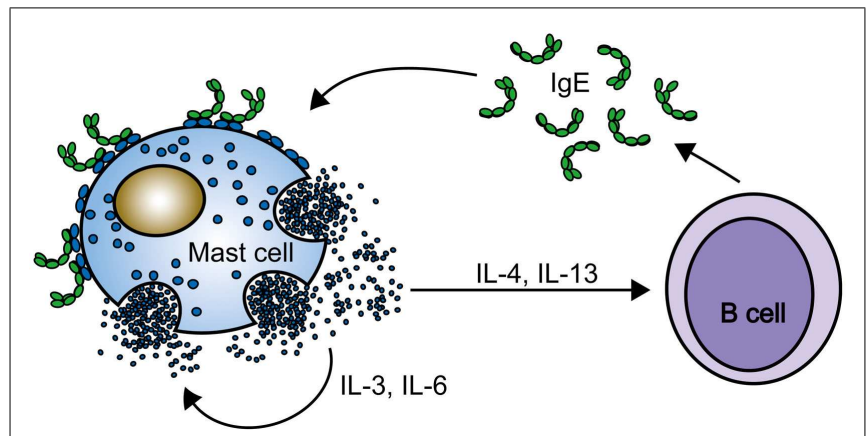

FIGURE 2 | A positive feedback loop. Mast cell activation by cytokinergic $\mathrm{IgE}$ induces cytokine secretion by mast cells in the absence of antigen. The cytokines stimulate mast cell survival and class switching to $\lg E$ in B cells. Continued production of $\lg E$ and cytokines occurs in the absence of antigen.
H1 DNP- -206 was comparably stimulated only by antigen. When SPE-7 or H1 DNP- $\varepsilon-206$ IgEs were incubated in media containing varying proportions of wild type BMMC and the FceRI-deficient FceRI ${ }^{-/-}$mutant BMMC, only SPE-7 IgE provoked the wild type cells to secrete cytokines that rescued the FcERI-deficient cells from apoptosis. Neutralization of IL-3, but not stem cell factor (SCF), ablated this activity in accordance with the later demonstration of IL-3's importance for mast cell survival in the absence of antigen (Kohno et al., 2005). The differential potency of the IgEs extended to the relevant signaling cascades. Thus, SPE-7 IgE, but not $\mathrm{H} 1$ DNP- $\varepsilon-206$ IgE triggers tyrosine phosphorylation and activation of ERK1, ERK2, p38, and Akt (Kitaura et al., 2003). Mice deficient in the kinases implicated in antigen-IgE signal transduction, namely Syk, Btk, and Lyn, were investigated. It transpired that only Syk was required for the stimulation of survival and cytokine synthesis/secretion by cytokinergic IgEs, whereas the full range of HC $\mathrm{IgE}$ activities needed the signaling action of the additional kinases.

The same authors tested the effect of injecting IgE- and $\mathrm{IgG}_{2 \mathrm{~b}}$ expressing hybridoma cells into mice on the accumulation of mast cells in different bodily locations. The greater accumulation of mast cells in the gastrointestinal tracts of mice injected with $\mathrm{H} 1$ DNP- $\varepsilon-26$, rather than with H1 DNP- -206 IgE or with the $\operatorname{IgG}_{2 b}$ secreting hybridoma cells, confirmed the pro-inflammatory activity of HC vs. PC IgE in vivo, though without definitive information on the mechanism (see Mechanisms of Cytokinergic Activity).

\section{HUMAN CYTOKINERGIC IgE}

The potential implications of cytokinergic IgE for human health and disease prompted the investigation of cytokinergic IgE activity in human mast cells. The first indications came from Gilchrest et al. (2003), who showed that a myeloma IgE alone stimulated I-309 (CCL-1) mRNA expression and release of I-309 protein from human cord blood-derived mast cells (CBMC) cultured with growth factors, but deprived of these before the assay. I-309 (CCL-1) is the ligand for the CCR8 receptor and is responsible for chemoattraction of T helper 2 (Th2)-type $\mathrm{T}$ cells, associated with allergic inflammation. The IgE also induced the secretion of GM-CSF and MIP-1 $\alpha$. These results suggest that human IgE, through the production and release of cytokines such as I-309, GM-CSF, and MIP- $1 \alpha$, could promote an inflammatory reaction in the absence of antigen stimulation of the mast cells. Next, Matsuda et al. (2005) showed that a myeloma IgE from the same commercial source as Gilchrest's induced secretion of IL-8 and monocyte chemoattractant protein 1 (MCP-1) from CBMC. It was found in both studies that addition of IL-4 to the standard culture medium at a late stage before withdrawal of growth factors led to a more robust response (Gilchrest et al., 2003; Matsuda et al., 2005). This can be understood in terms of the effects of IL-4 and IgE on mast cell differentiation and up-regulation of FceRI (Yamaguchi et al., 1999; Lorentz et al., 2005).

More dramatically, Cruse et al. (2005) showed that a myeloma IgE from a different commercial source than Gilchrest's and Matsuda's, stimulated human lung-derived cultured mast cell (HLMC) survival, IL-8 and leukotriene synthesis/secretion, and histamine release and associated $\mathrm{Ca}^{2+}$ influx and thus could be described as a human HC IgE. To determine whether this was a consequence of the type of IgE (cf. murine H1 DNP- -206 vs. SPE-7 IgE) or 
the use of HLMC in place of CBMC would require comparison of the different IgEs in the two types of mast cells. The same group later demonstrated that the cytokinergic activity of their IgE depended on the autocrine activity of IL-6 (Cruse et al., 2008), a well-known survival factor for CBMC and LMC (Yanagida et al., 1995; Oskeritzian et al., 2004). Thus, it is clear that certain human IgEs are indeed cytokinergic. Later studies demonstrated that polyclonal human IgEs from atopic dermatitis $(\mathrm{AD})$ patients also exert cytokinergic activities (see Effects of Polyclonal IgEs).

\section{EFFECTS ON MAST CELL MOTILITY, MIGRATION, AND ADHESION}

Strikingly, studies of allergy in the mouse model have shown that mast cells can be attracted to HC IgEs in vitro and in vivo (Kitaura et al., 2005). This was based on a comparison of three IgEs, the "typical" HC SPE-7 IgE and PC IgEs H1 DNP- $\varepsilon-206$ and IgE-E3 in an in vitro transwell migration assay. In this technique cells placed in the upper well migrate toward IgE in the lower well. In the case of SPE-7 IgE migration was a function of IgE concentration (between 1 and $30 \mu \mathrm{g} / \mathrm{ml}$ ). With H1 DNP- -206 and IgE-E3 by contrast, the cells failed to migrate. The kinetics of the migration of the cells toward SPE-7 IgE were similar to those of IgE-sensitized BMMC migrating toward DNP-HSA. This did not occur when BMMC from FceRI $\alpha^{-/-}$mice were placed in the upper well. In marked contrast, BMMC from the FceRI $\alpha^{-/-}$mice responded vigorously to SCF in control experiments. Wild type BMMC pre-sensitized with PC IgEs also migrated toward DNPHSA. Migration of BMMC toward the HC IgE was specific to both IgE isotype and antigen. It was necessary to coat the filter between the wells with fibronectin, vitronectin, or laminin, but not by coating with collagen and bovine serum albumin (BSA). Migration was inhibited in the presence of a blocking antibody against integrin $\beta 1$ (Kitaura et al., 2005). These effects are consistent with the observations on HC IgE induced adhesion and spreading of mouse mast cells on fibronectin-coated plates (Kitaura et al., 2005), and for calcium signaling, actin assembly, and membrane ruffling and spreading of cells of the rat basophilic leukemia cell line (Oka et al., 2004; Pandey et al., 2004).

The corresponding in vivo experiments were conducted by epicutaneous application of the same HC and PC IgEs. Skin samples from the mice were stained for mast cells with total and degranulating mast cell numbers counted. The accumulation of mast cells was greater in the mice treated with SPE-7 IgE than with H1 DNP$\varepsilon-206$ IgE, and similar to the numbers resulting from application of antigen to the same site $24 \mathrm{~h}$ after that of H1 DNP- $\varepsilon-206$ IgE.

\section{EFFECTS OF POLYCLONAL IgEs}

Experiments with different monoclonal IgEs were central to the discovery of cytokinergic activity. Yet the conditions differed from those in which mast cells encounter polyclonal IgEs in the physiological state. To simulate this situation Kitaura et al. (2003) performed experiments with a mixture of $\mathrm{HC}$ and PC monoclonal antibodies, which showed that their cytokinergic activity was simply the average of their individual contributions. To develop a more physiological assay for polyclonal IgE, Kashiwakura et al. (2009) injected mice with a mixture of the house dust mite antigen (Der $f$ ) and $S$. aureus enterotoxin B (a T cell superantigen) to stimulate a vigorous IgE response, an approach designed to provide a model of AD (Kawakami et al., 2007). Sera from the AD mice, containing ca. $50 \mu \mathrm{g} / \mathrm{ml}$ of IgE, and from wild type controls containing $<0.5 \mu \mathrm{g} / \mathrm{ml} \mathrm{IgE}$ were added at $10 \%$ of total volume to BMMC, and the survival of the cells and cytokine secretion were assayed. Only the AD sera stimulated both survival of the cells and IL-6 and IL-13 secretion. Depletion of IgE from the sera reduced the effects on survival and cytokine secretion; the effects of $\operatorname{IgE}$ were not observed with BMMC from FceRI ${ }^{-1-}$ mice. Using a different model of $\mathrm{AD}$, in which wild type and $\mathrm{IgE}^{-/-}$mice were sensitized by epicutaneous injection of ovalbumin, the authors confirmed that polyclonal IgE promotes mast cell survival and cytokine secretion.

To translate these findings into a human system, Kashiwakura et al. (2009) incubated human CBMC with a $10 \% \mathrm{v} / \mathrm{v}$ dilution of serum from $\mathrm{AD}$ patients containing $0.5-12 \mu \mathrm{g} / \mathrm{ml}$ of $\mathrm{IgE}$, or of serum from healthy controls, and measured the secretion of IL8 . The $\mathrm{AD}$ sera were significantly more active than non-AD sera and depletion of IgE from $\mathrm{AD}$ sera reduced the stimulation of IL-8 secretion to the level attained in non-AD sera. If the polyclonal IgE from the $\mathrm{AD}$ patients were a mixture of $\mathrm{HC}$ and $\mathrm{PC}$ IgE, this would account for the relatively small effects observed in these experiments. However, the concentrations in skin may be sufficient to cause or exacerbate the symptoms of $\mathrm{AD}$.

\section{DIVERGENT PATHWAYS OF SIGNAL TRANSDUCTION}

Kalesnikoff et al. (2001) were the first to point out the difference in the kinetics of mast cell activation by $\operatorname{IgE}$ in the presence and absence of antigen (see Effects on Mast Cell Activation). While antigen-triggered mast cell activation is stronger it is of short duration, peaking in minutes, and complete within an hour. By comparison, the activation of mast cells by cytokinergic IgE is delayed and sustained for several hours (Kalesnikoff et al., 2001). It was surmised that the prolonged time course reflected the slow, asynchronous binding of $\mathrm{IgE}$ and assembly of the complexes into lipid rafts within the cell membrane. Disruption of the rafts instantly terminated signal transduction. Prolonged stimulation by IgE alone may be required for the de novo generation of IL-3 and the survival of mast cells, but weak signaling may fail to drive mast cell degranulation. Simultaneous binding and clustering of the IgE-FceRI complexes by multivalent allergens may pass the threshold of stimulation required to induce cell degranulation; then the signaling would be rapidly terminated by internalization of the complexes.

Later studies confirmed these observations, clarified the points at which the signaling pathways diverge and identified the resulting downstream events (Charles et al., 2004; Kitaura et al., 2004; Pandey et al., 2004; Sakurai et al., 2004; Yamasaki et al., 2004, 2007; Kohno et al., 2005; Nunomura et al., 2005; Sly et al., 2008). Sly et al. (2008) propose that the weak but sustained ERK phosphorylation in the pro-survival pathway triggers a more prolonged $\mathrm{Ca}^{2+}$ influx, associated with the generation of reactive oxygen species (ROS) required for induction of IL-3 synthesis. This is not seen with antigen-dependent stimulation of mast cells. Inhibition of ROS generation with pharmacological inhibitors, e.g., the phospholipase $\mathrm{C}$ inhibitor U73122, converts slow to fast kinetics, while the addition of $\mathrm{H}_{2} \mathrm{O}_{2}$ results in IL-3 expression and increased survival of mast cells. 
Sly et al. (2008) suggest that local IgE synthesis, regardless of specificity, promotes mast cell survival in mucosal tissues in a positive feedback mechanism (Figure 2). Interestingly, IgE is required to maintain contact sensitivity, although antigen binding to IgE is not involved (Bryce et al., 2004). These authors showed that IgE was not required for the homing of mast cells to mucosal tissues, but was required for the up-regulation of FceRI on the resident mast cells. Accordingly, the mutual dependence of IgE and FceRI may represent a homeostatic mechanism in immune defense, associated with the risk of developing allergic disease. Investigations on the signaling pathways of cytokinergic IgE are converging with those on environmental pollution concerned with the effects of oxidative stress in the exacerbation of asthma (Swindle and Metcalfe, 2007; Swindle et al., 2007; Chung and Marwick, 2010; Peden, 2011). Knowledge of the mechanisms involved in the generation of ROS by cytokinergic IgE may contribute to the rational design of future strategies to diminish the impact of pollution (see Germinal Center Reactions and the Local B Cell Repertoire).

\section{MECHANISIMS OF CYTOKINERGIC ACTIVITY Is CYTOKINERGIC IgE ACTIVITY AN ARTIFACT OF ADVENTITIOUS IgE AGGREGATION?}

We consider first the possibility that has been raised of a trivial explanation for the cytokinergic activity of IgE, based on an adventitious aggregation process. Such a mechanism would imply an intrinsic propensity of IgE to aggregate in solution. Mast cell activation can be nucleated by bringing just two molecules into close proximity and then amplified by more extensive cross-linking to form larger clusters (Segal et al., 1977; Fewtrell and Metzger, 1980; Field et al., 1997). The notion that IgE must be cross-linked by antigen to initiate a signal in mast cells is so firmly entrenched as to lead to a common suspicion that pre-existing aggregates in the IgE preparations must be responsible for cytokinergic activity. That this is not so was painstakingly established by HPLC purification of monomeric IgE in essentially all of the studies. It was further shown that purified aggregates have no activity and that their reconstitution with the monomeric IgE fraction does not increase IgE activity (Kalesnikoff et al., 2001). Neither does prolonged storage or pre-incubation of the IgEs with the BMMC affect their activity. Neither is reversal of the cytokinergic activity by specific monovalent hapten binding (Asai et al., 2001; Pandey et al., 2004) compatible with adventitious IgE aggregation.

\section{NATURE OF THE "ACTIVE SITES" IN CYTOKINERGIC IgE}

Clustering of HC IgE in the mast cell membrane and signaling through FceRI implies that complexes with receptor encounter each other directly or indirectly through one or more other molecule(s). How does this occur? The available evidence points to the involvement of contact sites in the $\mathrm{N}$-terminal ( Fv) domains of IgE when it is bound to FceRI on the mast cells. The fact that monoclonal IgEs with different variable regions, regardless of specificity, linked to the same $(\varepsilon)$ constant region, exhibited varying degrees of cytokinergic activity implicates this domain. One caveat is that differential glycosylation of PC and HC IgE may vary the exposure of a potential "active site" in the Fc region of IgE. A key role for the Fv domain is also supported by the observation that specific monovalent haptens inhibit the cytokinergic activity, as noted above. The hapten may simply occupy the "active site" or binding may stabilize an alternative conformation of the domain in which the site is occluded or deformed. We enlarge upon the latter possibility below and in Sections "Conformational Isomerism of SPE-7 IgE Facilitates Binding to Structurally Unrelated Antigens" and "Conformational Isomerism as a Basis of Cytokinergic Allergy?"

The rank order of cytokinergic activities of different IgEs was preserved in BMMC tested in serum-free medium (Kitaura et al., 2003). Even in the earlier work of Kalesnikoff et al. (2001) the medium was supplemented solely with BSA and IgE. Thus no extrinsic proteins (other than BSA in some experiments) were present in these systems. The reversal of cytokinergic activity when the unbound IgE is removed from the medium may favor a model in which the free $\operatorname{IgE}$ acts as a bridge between two bound $\operatorname{IgE}$ molecules (Figure 3B). The participation of both Fv domains of the bound IgE is implied by the necessity to form clusters containing more than two IgE-FceRI complexes. The rank order of cytokinergic activities may reflect the strength of the IgE-IgE (or $\operatorname{IgE}-\mathrm{X}-\mathrm{IgE}$ ) interactions, which is likely to be determined by the highly diverse antigen binding sites in different HC IgEs. The inference is that cytokinergic activity may arise from conformational lability of the Fv domains, allowing exposure of "active sites". Hapten binding would then stabilize the preferred conformation, resulting in the observed loss of cytokinergic activity. The nature of the interactions has so far proved elusive.

To gain further insight into the structural requirements for cytokinergic activity we constructed recombinant human IgEs with different combinations of $\mathrm{V}_{\varepsilon}$ and $\mathrm{V}_{\mathrm{L}}$ sequences. $\mathrm{V}_{\varepsilon}$ and $\kappa$ or $\lambda \mathrm{V}_{\mathrm{L}}$ cDNA sequences cloned from the nasal mucosa of allergic rhinitis patients (Coker et al., 2003) were used for this purpose. The cytokinergic activities of IgEs with random combinations of $\mathrm{V}_{\varepsilon}$ and $\mathrm{V}_{\mathrm{L}}$ were tested in either human peripheral blood-derived cultured mast cells (PBMC; Gould et al., preliminary results)

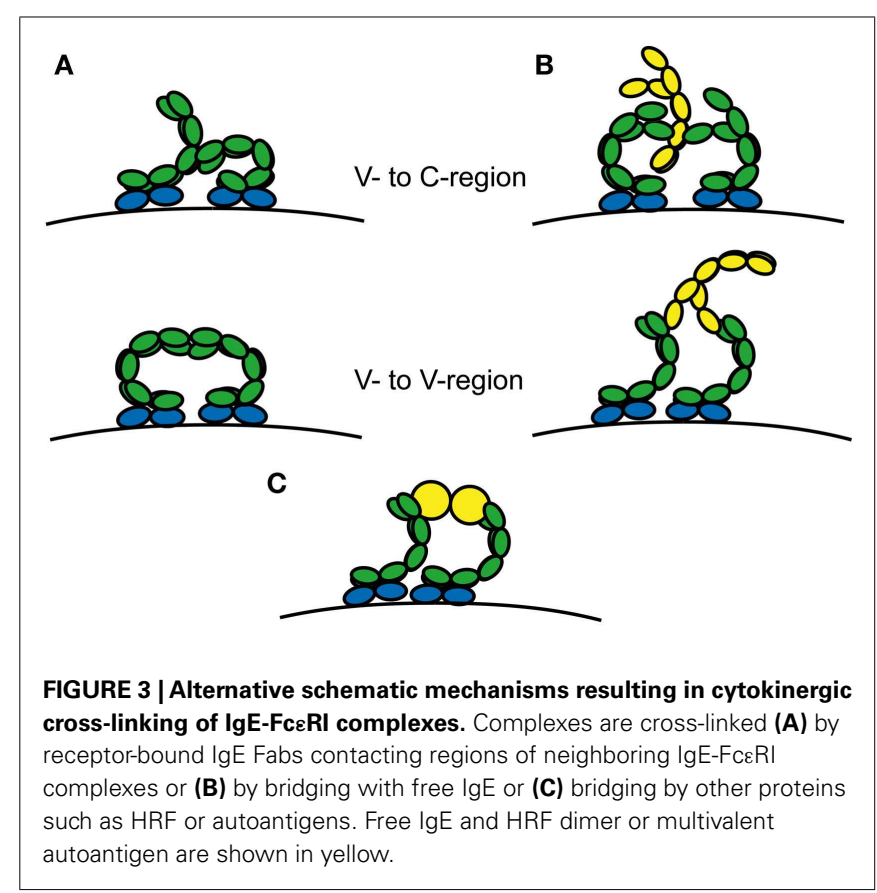


or in CBMC (Kawakami, personal communication) by assaying $\beta$-hexosaminidase release (degranulation) and/or IL- 8 cytokine secretion. Independent experiments in the two laboratories led to the same conclusion. Thus, a given $V_{L}$ combined with one $V_{\varepsilon}$ was highly cytokinergic, while in combination with a different $\mathrm{V}_{\varepsilon}$ it exhibited only vestigial activity. Likewise, the cytokinergic activity was not consistently associated with the presence of a particular $\mathrm{V}_{\varepsilon}$ sequence. About one-third of all the recombinant IgEs exhibited a range of activities up to the level observed with mouse SPE-7. These results suggest that the conformation of the whole Fv domain may be important in determining the cytokinergic activity of an IgE; further experiments comparing the cytokinergic activities of recombinant IgEs with natural and scrambled $\mathrm{V}_{\varepsilon}$ and $\mathrm{V}_{\mathrm{L}}$ pairs are in progress to resolve this question. In the following sections we review what is known about the conformational properties of antibody Fv regions and how they may impact on cytokinergic activity.

\section{CONFORMATIONAL ISOMERISM OF SPE-7 IgE FACILITATES BINDING TO} STRUCTURALLY UNRELATED ANTIGENS

Antibodies are generated by the adaptive immune system to bind to a seemingly unlimited range of antigens. The initial response occurs through an interaction with a pre-existing polyclonal population of IgM-expressing B cells. The diversity of potential binding specificities is generated by the quasi-random combinatorial recombination of the $\mathrm{V}, \mathrm{D}_{\mathrm{H}}$, and $\mathrm{J}$ gene segments encoding the variable regions of the Ig heavy- and light-chains. There is an accompanying contribution to diversity by non-templated nucleotide insertions and deletions at the $\mathrm{D}_{\mathrm{H}}-\mathrm{J}_{\mathrm{H}}$ junction. However, in practice, the comparatively low number of the body's circulating primary germline-repertoire B cells (ca. 106) limits this genetic diversity. The extra diversity required for recognition of a wider range of potential antigens originates, it has been suggested, comes from conformational flexibility of the complementaritydetermining region (CDR) loops (Stevens et al., 1988; James and Tawfik, 2003a; Thielges et al., 2008). Historically, structural evidence for this conformational diversity within a germline antibody was inferred indirectly from comparisons of the bound and free germline, and affinity-matured, hapten-specific antibodies
(Wedemayer et al., 1997; Yin et al., 2003). Recently, Salunke and co-workers have directly shown that germline antibodies can adopt multiple conformations (Khan and Salunke, 2012), with additional diversity conferred by polyreactivity of individual conformers (James and Tawfik, 2003a,b; Sethi et al., 2006). Direct evidence came from kinetic analysis of hapten binding to affinitymatured antibodies (Lancet and Pecht, 1976; Foote and Milstein, 1994; James et al., 2003; Figure 4).

Affinity maturation leads to antibodies that bind to their antigen with higher affinity and thus specificity than their germline precursors. This can arise directly through selection of more favorable side chains for antigen binding or indirectly by restricting the conformational flexibility of the CDR loops so as to favor the conformation that the antibody must adopt in its complex with the cognate antigen (Zimmermann et al., 2006, 2010; Thorpe and Brooks, 2007). Indeed, more than $90 \%$ of the affinity-matured antibodies studied by Foote and Milstein associate through a single-step mechanism. The pre-rigidification in such a "lock-and-key" mechanism (Figure 5) improves binding by reducing the entropic penalty of freezing out flexible loops (Manivel et al., 2000) and accelerating the association rate constant (Foote and Milstein, 1991). Conformational repositioning can also occur upon antigen binding (Rini et al., 1992) as a result of an "induced-fit" mechanism, whereby an initial low-affinity bimolecular complex forms, which only then undergoes a rearrangement to yield the final high-affinity complex (Figure 5). These changes in the structural dynamics also act to increase antibody specificity.

Even though SPE-7 IgE is a DNP-specific antibody of highaffinity $\left(K_{\mathrm{d}}=2 \times 10^{-8} \mathrm{M}\right.$, James et al., 2003), stopped-flow kinetic experiments revealed that the antigen-free state comprises at least, two conformational isomers. Complementary structural studies showed that the preponderant form, $\mathrm{Ab}^{1}$ (making up some $80 \%$ of the SPE-7 molecules) has a broad and flat conformation that resembles the state in antibody-protein complexes. By contrast, the minor constituent, $\mathrm{Ab}^{2}$ (ca. 20\% of SPE-7 molecules) has a deep and narrow conformation, reminiscent of antibody-hapten complexes (James et al., 2003; Raghunathan et al., 2012; Figures 4 and 5). The presence of the two conformers enables SPE-7 to bind
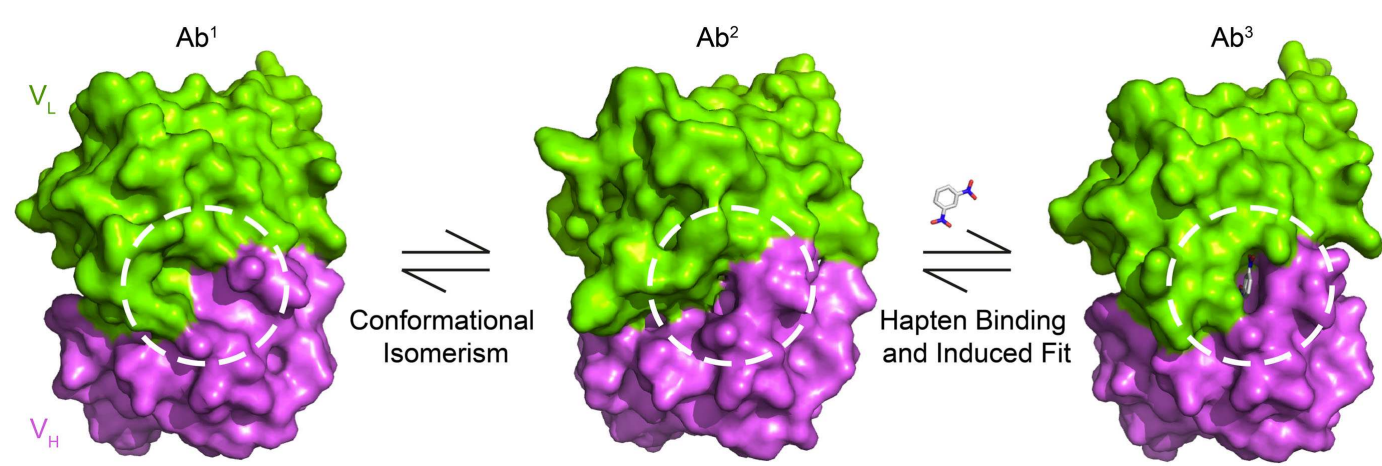

FIGURE 4 | Conformational changes in SPE-7 alter the shape of the protein surface. Antigen-free SPE-7 is in equilibrium between two conformers - $\mathrm{Ab}^{1}$ (pdb: 1OAQ) that binds proteins and $\mathrm{Ab}^{2}$ (pdb: 10CW) that binds haptens (James et al., 2003). While $A b^{1}$ has a broad and shallow surface around the key CDRH3 pocket (dashed circle), the pocket is deep, and narrow for $A b^{2}$. After hapten binding to $\mathrm{Ab}^{2}$ a further, induced-fit conformational change occurs resulting in the $A \mathrm{~b}^{3}$-hapten bound conformer (pdb: 1OAU). 


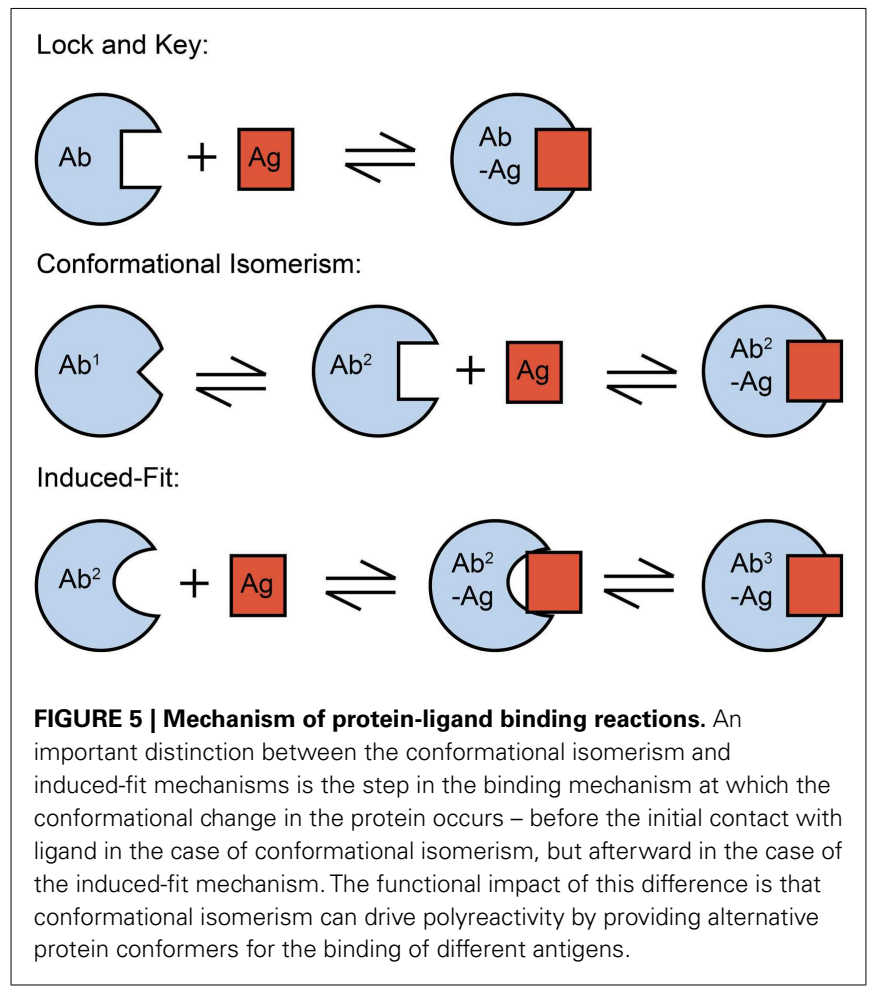

two types of completely unrelated antigens. Conformer $\mathrm{Ab}^{2}$ binds promiscuously to a variety of aromatic ring compounds, with a range of affinities between $20 \mathrm{nM}$ and $100 \mu \mathrm{M}$, while the bound state for the more weakly binding compounds essentially resembles the $\mathrm{Ab}^{2}$ conformer. Compounds of higher affinity (including the immunizing hapten, DNP-Lys) engender an "induced-fit" rearrangement to a third state, $\mathrm{Ab}^{3}$ (James and Tawfik, 2003b, 2005; James et al., 2003; Figure 4). Although a physiological in vivo binding partner for the $\mathrm{Ab}^{1}$ conformer has yet to be identified, a phage display selected thioredoxin homolog was found to bind to it (Figure 6A), suggesting that such an interaction could occur in vivo (James et al., 2003).

The crystal structure of the IgM rheumatoid factor, RF-AN, bound to its autoantigen $\left(\mathrm{IgG}_{4} \mathrm{Fc}\right)$ is instructive in this context (Corper et al., 1997), for it shows that, rather than attaching to conventional antibody-protein-binding CDR loop, it binds at the edge of the loops, leaving much of the usual antigen binding site exposed. While conformational isomerism has not been kinetically demonstrated for RF-AN (Figure 6B), its mode of binding resembles that of the SPE-7 $\mathrm{Ab}^{1}$-thioredoxin interaction (Figure 6A). These examples complement each other as for SPE-7 the immunizing antigen is known but not the true in vivo cross-reactive protein, and vice versa for RF-AN.

\section{CONFORMATIONAL ISOMERISM AS A BASIS OF CYTOKINERGIC ALLERGY?}

Many of the properties of SPE-7 IgE are shared with other antibodies. Thus, just like the SPE-7 $\mathrm{Ab}^{2}$ conformer, many antibodies show cross-reactivity against antigens with similar, though not necessarily identical structure to that of the immunizing antigen. This "molecular mimicry" in fact, plays an important

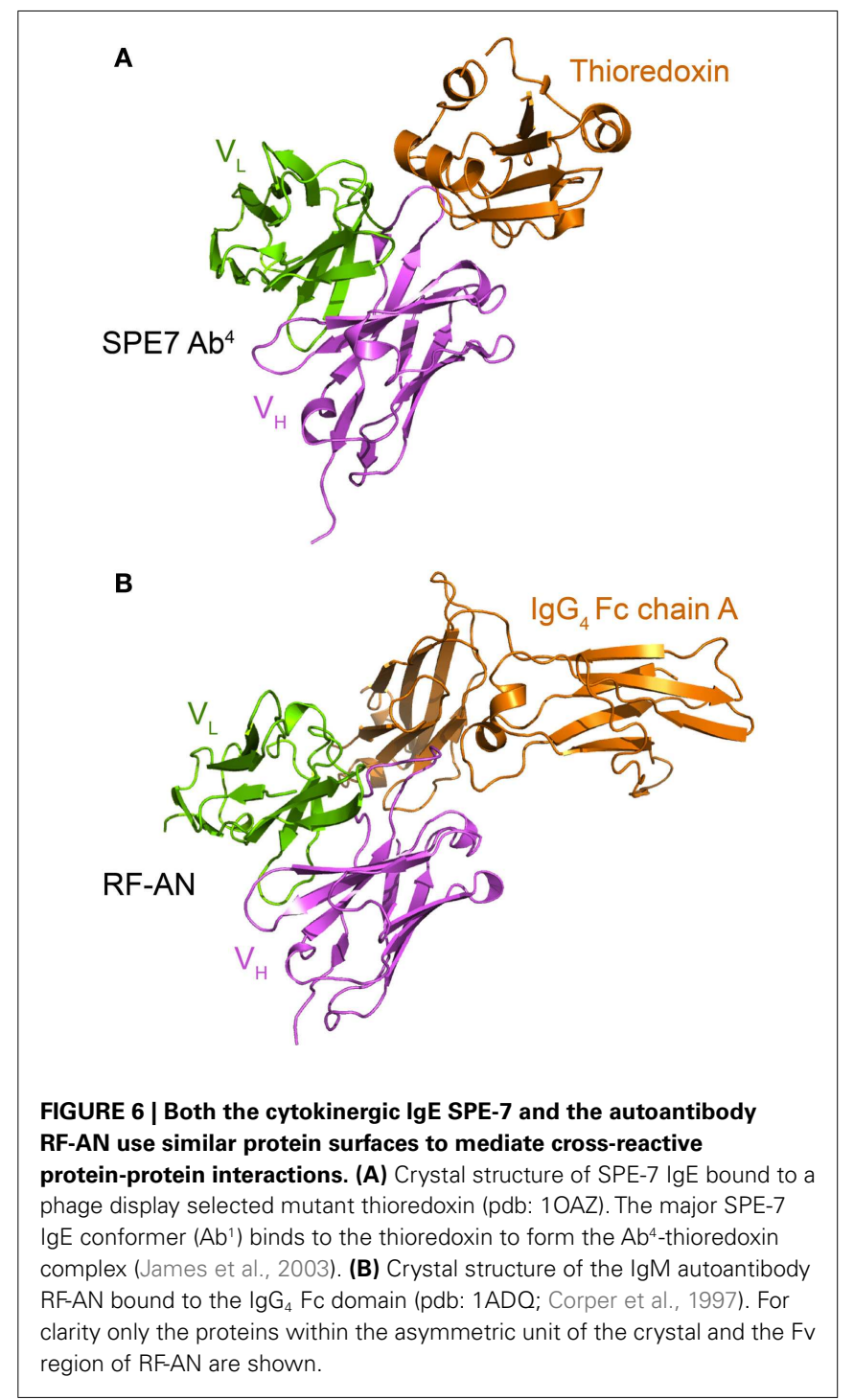

role in allergy (Valenta et al., 1991, 2009; Spitzauer et al., 1994; Aalberse et al., 2001; Schmid-Grendelmeier et al., 2005) and autoimmunity (Rashid and Ebringer, 2012). Moreover, other affinity-matured antibodies have been shown by kinetic criteria to display conformational isomerism; this pertains to as many as $10-20 \%$ of those raised against the hapten phenyloxazolone (Lancet and Pecht, 1976; Foote and Milstein, 1994). Further, unrelated antigens have been shown to bind to different conformers of other antibodies (e.g., antibody D1.3 binds to lysozyme and to the antibody E225; Bentley et al., 1990). Therefore, it is highly unlikely that conformational isomerism is unique to SPE-7 IgE, and may be inferred to extend to other IgEs. In the context of cytokinergic IgE activation of mast cells, conformational isomerism may provide a state with the capacity for additional protein-binding interactions. This could be to a third protein, to free IgE, or to another self-protein, thereby bridging two IgE-FceRI complexes (Figures 3B,C). Alternatively, adjacent IgE-Fc\&RI complexes may contact each other directly (Figure 3A). 


\section{A DIFFERENT KIND OF CYTOKINERGIC ACTIVITY: HISTAMINE-RELEASING FACTOR}

Heterogeneity in the cytokinergic function of IgEs immediately brings to mind a similar phenomenon that had already puzzled workers for over 30 years (MacDonald, 1996). Allergic individuals were classified according to two groups, responders or nonresponders, depending on the ability of their serum IgE to sensitize mast cells and basophils for the release of histamine, cytokines, and leukotrienes by a protein present in lavage fluids obtained from allergic lesions. $\operatorname{IgE}^{+}$was able to sensitize basophils from both responders and non-responders, whereas $\mathrm{IgE}^{-}$was inactive in the absence of allergen, placing the responsibility firmly on $\operatorname{IgE}$ (MacDonald et al., 1987). Histamine-releasing factor (HRF) was purified and the gene cloned, showing its identity with a previously known protein called translationally controlled tumor protein (TCTP), which has a wide range of functions (MacDonald et al., 1995). Thus the obvious candidate as HRF receptor appeared to be $\operatorname{IgE}^{+}$itself, but the first attempts to demonstrate direct binding to IgE were unsuccessful (Wantke et al., 1999).

This may have been due to unfavorable experimental conditions (perhaps the limited range of IgEs or the assay conditions). Nevertheless, in early 2012 binding of recombinant mouse HRF to certain mouse monoclonal $\mathrm{IgE}^{+}$and $\mathrm{IgG}^{+}$preparations and to polyclonal mouse $\mathrm{IgE}^{+}$was demonstrated (Kashiwakura et al., 2012a). The use of a large panel of monoclonal Igs together with BMMC revealed that recombinant HRF bound with varying strength to about one-third of the Igs, and that potency of the IgEs in assays of HRF-induced airway inflammation was roughly correlated with this binding activity. Injection of the HRF into mice of different genetic deficiencies showed that the airway inflammation is dependent on mast cells, B cells, FceRI, and the FcR $\gamma$-chain. Monoclonal $\operatorname{IgE}^{+}$, but not $\mathrm{IgE}^{-}$induced passive cutaneous anaphylaxis in mice, mediated by FceRI - a further demonstration of in vivo activity.

The structural properties of $\mathrm{IgE}^{+}$were investigated. Their Fabs were as active in binding HRF as intact IgE molecules, and binding was inhibited by antigen, implying that HRF binds at a site in the variable regions. Interestingly, there appeared to be a relation to the presence of $\kappa$-chains derived from two particular members of the $\kappa$ germline gene family (8-30 and 2-137), paired with heavychains from different $\mathrm{V}_{\mathrm{H}}$ families. Recombinant HRF was also split into smaller fragments, two of which inhibited HRF activities in vitro and in vivo in mice. The activity of the corresponding HRF peptides in the human system remains to be evaluated; clinical applications may be envisaged.

The native HRF is a dimer with two disulfide bonds uniting the subunits. Cysteine to alanine mutations or reduction of the disulfide bonds eliminated the activity in $\mathrm{IgE}^{+}$-mediated BMMC or peritoneal mast cell activation (Kashiwakura et al., 2012a). These authors propose a model to explain how dimeric HRF molecules are able to cross-link IgE-FceRI complexes to activate the mast cell (Figure S8 in Kashiwakura et al., 2012a). The presence of two different inhibitory sequences in HRF implies the existence of two different contact sites in each $\operatorname{IgE}^{+} \mathrm{Fv}$. A simplified form of the complex, utilizing one Fv in each of two adjacent IgE-FceRI complexes and only one of the contact sites in each subunit of the HRF dimer is represented in Figure 3C. It is easy to envisage how such a complex might nucleate larger clusters through the vacant contact sites to form an effective signaling platform for mast cell activation.

The lack of cytokinergic activity of $\operatorname{IgE}^{+}$, even at high concentrations, in the absence of HRF, and the lack of HRF responsiveness of SPE-7 IgE and other HC IgEs (at low concentrations) show that the two activities are not equivalent (Xie et al., 2008; Kashiwakura et al., 2012a). However, neither $\mathrm{HC} \operatorname{IgE}$ nor $\operatorname{IgE}^{+}$require the presence of an antigen, and therefore both may be considered as "cytokinergic IgEs" according to the original definition (Kitaura et al., 2003).

The examples here of $\mathrm{HC}$ and $\mathrm{IgE}^{+}$illustrate the potential for multiple mechanisms of cytokinergic IgE activity. Both HC IgE and $\mathrm{IgE}^{+}$are evidently involved in allergic inflammation in the absence of allergen. Both are implicated in the exacerbation of atopic asthma and allergy. Cytokinergic IgE activity may provide a rationale for the paradoxical observation that the risk of developing an "allergic disease" and severity of the disease is more closely related to the levels of total IgE than allergen-specific IgE in serum (Burrows et al., 1989; Sunyer et al., 1996; Beeh et al., 2000). It may also account for "allergic disease" in non-atopic patients, in whom the usual skin prick tests for allergen sensitivity and serum titers of allergen-specific IgE are negative, but who present with the usual signs and symptoms of allergic disease (see Germinal Center Reactions and the Local B Cell Repertoire).

\section{CYTOKINERGIC ACTIVITY OF IgE VIA FC\&RI IN OTHER CELLS OR MEDIATED BY OTHER IgE RECEPTORS}

Cells other than mast cells and basophils express FcERI (the "highaffinity" IgE receptor) and many types of cells express CD23 (the "low-affinity" IgE receptor). FceRI is expressed in Langerhans cells, dendritic cells, monocytes, smooth muscle cells, and epithelial cells, while CD23 is expressed in many of these cell types and also in B cells, T cells, and follicular dendritic cells (Gould et al., 2003; Gould and Sutton, 2008). There are two splice variants of human CD23, CD23a, and CD23b, differing in 6/7 amino acids at the cytoplasmic N-terminus; these are expressed in different circumstances and have different functions (Gould et al., 2003; Gould and Sutton, 2008). Galectin-3, also known as Mac-1 and IgE binding factor (Huff et al., 1983), binds to both IgE and FceRI, amongst other ligands (Liu, 2005). Early experiments with BMMC from mice in which the genes were inactivated argue against a role for CD23 or galectin-3 in mediating cytokinergic IgE activity (see Effects on Mast Cell Survival).

A recent study suggests that macrophages may exert cytokinergic IgE activity through $F_{c \varepsilon} \mathrm{RI}$ in an important physiological context - atherosclerosis (Wang et al., 2011). Serum IgE levels were elevated in two groups of Chinese patients with myocardial infarction or unstable angina pectoris. IgE and FceRI were observed in atherosclerotic lesions and localized to the majority of macrophages and a minority of smooth muscle cells and epithelial cells in the tissue. A fat diet was used to develop a mouse model of atherosclerosis. The disease was attenuated in FceRI $\mathrm{RI}^{-1-}$ and $\mathrm{TLR}^{-1-}$ mice suggesting synergistic activity between these receptors. IgE in the range of $6-100 \mu \mathrm{g} / \mathrm{ml}$ stimulated signal transduction and cytokine secretion by isolated macrophages from the mice and SPE-7 IgE was more potent than H1 DNP- -206 IgE. 
Weaker IgE responses could be induced in the smooth muscle cells and epithelial cells. The large discrepancy in the concentration of IgE required to activate mast cells and macrophages may reflect the relatively low levels of receptor expression or absence of the signal amplifier $\beta$-chain in these cells. Since there are few B cells in the tissue, IgE must be imported from the circulation. It is certainly questionable whether local IgE concentrations in heart tissue ever reach the levels required for macrophage activation, although heart mast cell involvement in cardiac disease is by now well established (Genovese et al., 2010).

No activities of HC IgE in IgE-expressing B cells have come to light. SPE-7 IgE hybridoma cells appear to grow normally and IgE levels in the culture media rise well above the concentrations required for cytokinergic activity in mast cells. High concentrations of the FceRI and the topology of HC IgE-FceRI complexes in the membrane of mast cells (and other FceRI bearing cells) may be critical for cytokinergic IgE activity (see Fab Pre-Orientation in the IgE-FceRI Complex on the Mast Cell Membrane). In so far as mast cells are implicated in diseases other than allergy, e.g., autoimmunity, HIV infection, and malaria, cytokinergic IgE may have a wider significance in disease pathogenesis.

\section{SECONDARY RECEPTOR EDITING AS A SOURCE OF CYTOKINERGIC IgES}

A cost/benefit balance is implicit in the possession of a large antibody-directed repertoire while precluding antibody targeting of self-antigens (Ehrlich's horror autotoxicus; Ehrlich, 1900). Induction of tolerance to self-antigens is inseparable from the prevention of autoantibody formation, given that after $\mathrm{V}\left(\mathrm{D}_{\mathrm{H}}\right) \mathrm{J}$ recombination in the bone marrow up to $75 \%$ of $\mathrm{B}$ cells are selfreactive (Wardemann et al., 2003; Nemazee, 2006). During B cell development within bone marrow, tolerance is achieved through a combination of deletion of self-reactive $\mathrm{B}$ cells and receptor editing. The editing involves exchange of the $\mathrm{V}$-segment attached to DJ-C $\mu$ for the heavy-chain, or of the J-Cк or J-C $\lambda$ for the light-chain, thereby altering the $\mathrm{B}$ cell receptor specificity, so that it no longer recognizes the self-antigen. It is now clear (Eisenberg, 2012) that, after release from the bone marrow, B cells that have migrated to peripheral lymphoid tissue can undergo further rounds of receptor editing, called "receptor revision." On the one hand, this may serve to eliminate self-reactive B cells that escape from the bone marrow or are generated by somatic hypermutation in the periphery. On the other, this process may generate polyspecific, autoreactive B cells anew, either before or after switching to IgE, that may exert cytokinergic activity. Studies on circulating B cells have shown that a significant proportion $(\sim 5 \%)$ produce polyspecific IgM and IgG (Wardemann et al., 2003; Nemazee, 2006), of which a proportion may be generated in the periphery.

The sequence of events in receptor editing and revision is itself well characterized. The Th2 inflammatory cytokine IL-6 induces the expression of RAG1 and RAG2, products of the recombination activating genes rag1 and rag2. A complex of RAG1 and RAG2 can itself initiate the process of receptor revision, since all the other machinery for repairing DNA breaks in cells is constitutive (Nemazee, 2006). RAG genes are normally silenced once a functional Ig is expressed in B cells, but may be re-expressed in the presence of IL-6 (Hillion et al., 2007a,b). IL-6 secretion is commonly observed when mast cells are stimulated by cytokinergic
IgE; when this occurs in the target organs of allergy, it may lead to the local expression of polyspecific/cytokinergic IgE.

Polyspecific IgE is well characterized in at least two pathological conditions, parasitic worm infection, and chronic sinusitis with polyps (ChRwP). Helminths induce Th2-type immune responses and regulatory $\mathrm{T}$ cells that produce anti-inflammatory cytokines. This is accompanied by the synthesis of abundant polyspecific IgE, little or none of which is specific for the parasite antigens (Harnett and Harnett, 2010). This appears to be the parasite's strategy to evade detection and elimination by the host immune system. Similarly, nasal polyps in ChRwP are characterized by the presence of abundant Th2 cytokines, regulatory T cells, and polyspecific IgE. Compelling evidence supports the hypothesis that $S$. aureus infection causes this polyposis, yet only small proportions of the IgE are directed against the bacterial proteins and allergens (Zhang et al., 2011). The high concentrations of polyspecific IgE may well exert cytokinergic activity, contributing to chronic inflammation and allowing $S$. aureus to exist in the commensal state. Re-expression of RAG1 and RAG2 in the nasal B cells and receptor revision may be instrumental in generating the polyspecific IgE to disarm the immune response.

\section{STRUCTURAL IMPACT OF SECONDARY EDITING ON Fv PROPERTIES}

After affinity maturation of binding to a specific antigen, residues from the three CDR loops on the heavy- or light-chains, and often both, directly contact the antigen, an event in which CDRH3 often plays a dominant role (Stanfield et al., 1993). CDRH3 lies close to the $\mathrm{V}_{\mathrm{H}}-\mathrm{V}_{\mathrm{L}}$ domain interface; the relative orientation of the domains changes on antigen binding (Stanfield et al., 1993; Teplyakov et al., 2011), and also in the course of affinity maturation, thus enhancing the affinity of antigen binding (Chatellier et al., 1996), as discussed in Section "Conformational Isomerism of SPE-7 IgE Facilitates Binding to Structurally Unrelated Antigens." The relative orientations of the $\mathrm{V}_{\mathrm{H}}-\mathrm{V}_{\mathrm{L}}$ domains vary considerably; thus one analysis of the crystal structures shows that their angular disposition varies between $-60.8^{\circ}$ and $-31.0^{\circ}$ (Abhinandan and Martin, 2010). Mutations at the $\mathrm{V}_{\mathrm{H}}-\mathrm{V}_{\mathrm{L}}$ interface also affect the structural stability of the Fv region (Chatellier et al., 1996; VargasMadrazo and Paz-Garcia, 2003; Nakanishi et al., 2008; Caravella et al., 2010). It appears then that after receptor revision the new $\mathrm{V}_{\mathrm{H}^{-}}$ $\mathrm{V}_{\mathrm{L}}$ may well be less stable than the original $\mathrm{Fv}$, thus alteration of the $\mathrm{V}_{\mathrm{H}}-\mathrm{V}_{\mathrm{L}}$ pairings could increase the conformational isomerism enabling antibodies to interact with themselves (self-association) or other proteins (Figure 3). Mutations at particular positions in the $V_{H}$ interface with $V_{L}$ have been used to create single chain antibodies, similar to those expressed in camels (Barthelemy et al., 2008). Certain $\mathrm{V}_{\mathrm{H}}-\mathrm{V}_{\mathrm{L}}$ combinations may actually result in domain swapping between IgEs bound to adjacent FceRI on mast cells, or between the bound and free IgEs (see below).

\section{DIMENSIONAL REDUCTION AND ORIENTATION MAY DRIVE SELF-ASSOCIATION OF Fc $\varepsilon$ RI-BOUND IgE}

The evidence so far available suggests that cytokinergic activity is related to receptor clustering on the surface of mast cells, and that HC IgEs induce more extensive clustering than PC IgEs (Kalesnikoff et al., 2001; Kitaura et al., 2003). This process must depend in large measure on the enormous increase in binding 
affinity that results when the reactants are confined in the plane of the membrane, by reason of their high concentration in two dimensions and their much-reduced orientational freedom (see e.g., DeLisi (1981) who calculates a reduction by a factor of about $10^{5} \mathrm{M}$ in $K_{\mathrm{d}}$ relative to the same reactants in free solution). The likelihood therefore is that, in the normally attainable concentration range, interaction between the molecules we are considering would be undetectably low in solution. Schweitzer-Stenner and Pecht (2005) have modeled the situation for varying numbers of FceRI molecules per cell. With typical numbers, e.g., $3 \times 10^{5}$ molecules/cell, the probability of productive collisions would be extremely high. Thus, given the mobility of receptors in the membrane, the ability of IgEs to self-associate after they bind to FceRI, is plausible. There is moreover ample evidence for Fab-mediated self-association of antibodies at high local concentrations; thus, Shire and co-workers have used the anti-IgE omalizumab as a case study for such a phenomenon (Yadav et al., 2012). This could occur, for example, through the variable region on one Fab contacting the variable or constant region on another (Figure 3A). A range of potential orientation modes for self-association has been observed crystallographically, with the most extreme case being domain swapping (Boehm et al., 2000; Lee et al., 2002; Calarese et al., 2003; Igawa et al., 2010; Figure 7).

\section{Fab PRE-ORIENTATION IN THE IgE-FcєRI COMPLEX ON THE MAST CELL MEMBRANE}

IgE possesses unique properties that may pre-dispose it to cytokinergic activity. The high-affinity of binding $\left(K_{\mathrm{d}} \sim 10^{-10} \mathrm{M}\right)$ and slow dissociation $\left(t_{1 / 2} \sim 14\right.$ days in tissue) imply that $\operatorname{IgE}$ is effectively permanently attached to FceRI on the cell membrane. IgE has one more pair of Ig domains in its Fc region than IgG, which causes IgE to adopt an asymmetrically bent structure (Wan et al., 2002; Hunt et al., 2012). The bend becomes more acute on binding to FceRI (Holdom et al., 2011; Hunt et al., 2012), causing the extra ( $\mathrm{C} \varepsilon 2)$ domains to orient the Fab domains away from the membrane, thus giving less obstructed access to the antigen (Figure 8). We surmise that the angular freedom of the Fabs allows the IgE to accept a wider range of antigens. Structural freedom may, on the other hand, also promote interactions with each other or other molecules to promote cytokinergic activity. We suggest that this structurally predetermined orientation of the Fabs may play an important role in predisposing the mast cells and other cells expressing Fc\&RI to cytokinergic IgE activation.

Activation of mast cells in the allergic response is initiated by antigen-induced cross-linking of cell surface IgE-FceRI. The optimum distance between the antigen epitopes was measured with rigid bivalent allergens (DNP-modified oligodeoxynucleotides), showing that there needs to be sufficient proximity of the crosslinked complexes ( $<70 \AA$ apart) for significant stimulation of degranulation, although signaling upstream of the $\mathrm{Ca}^{2+}$ response was unimpaired with greater distances between the epitopes (Paar et al., 2002). The crystal structures of two allergens each bound to two IgE antibody Fabs show an approximately linear structure (Li et al., 2008), compatible with the presentation of the Fabs oriented perpendicular to the membrane when IgE binds to FceRI on the mast cell (Niemi et al., 2007). Pre-orientation of the IgE Fabs

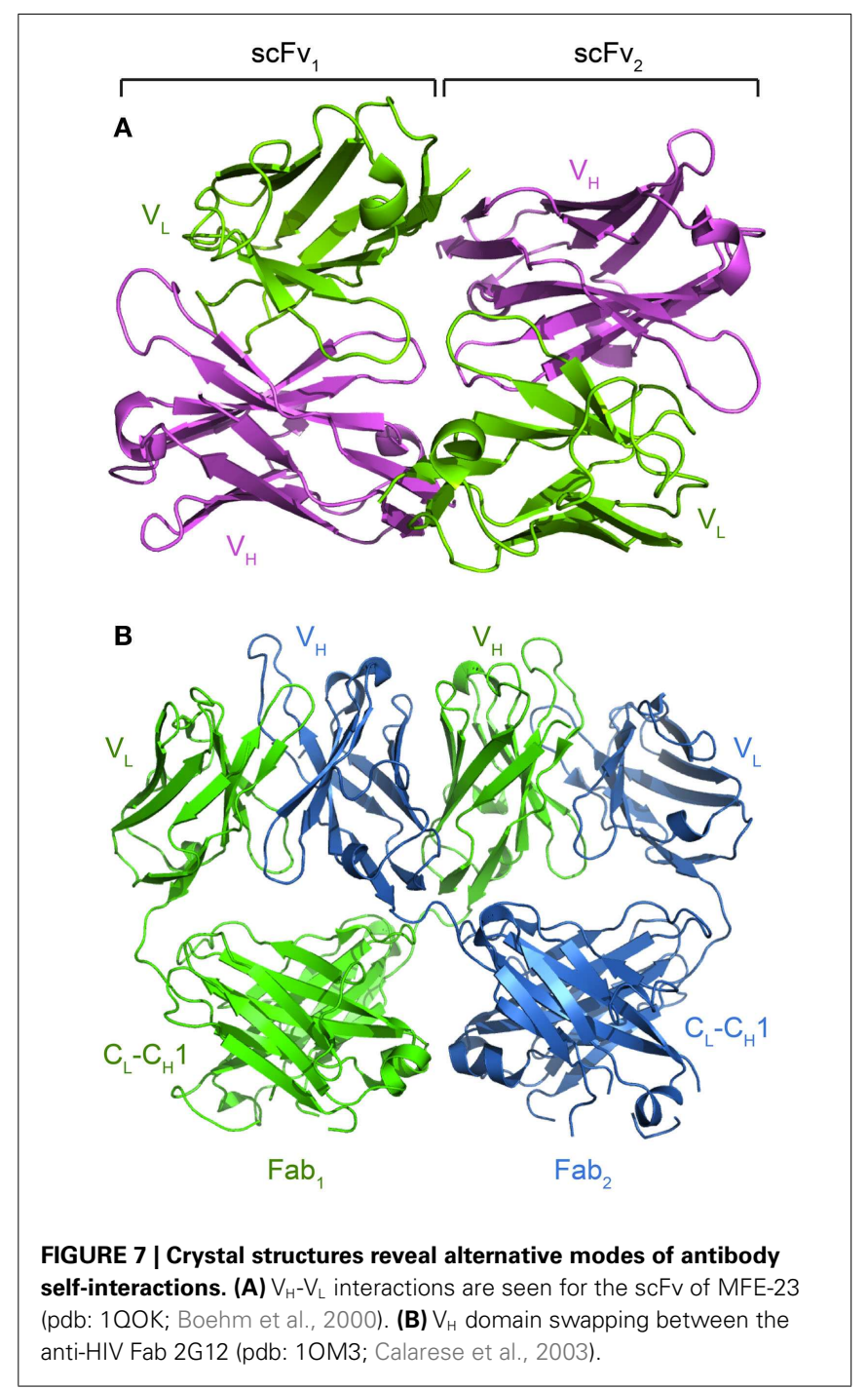

would also allow self-interaction or bridging, e.g., by free IgE or HRF (Figure 3).

\section{MOST HC IgES HAVE POLYREACTIVITY TO AUTOANTIGENS}

Human IgEs do not bind to mouse FceRI, but mouse IgE does bind to human FceRI (Conrad et al., 1983). Conveniently, this allows mouse IgEs, as well as human IgEs, to be tested for polyreactivity in human FceRI-expressing cells. To examine the relationship between cytokinergic IgE activity and polyreactivity Kashiwakura et al. (2012b) tested a number of well characterized mouse and human HC and PC IgEs for binding to a panel of autoantigens routinely used for the diagnosis of autoimmunity (single- and double-stranded DNA, thyroglobulin, $\beta$-galactosidase) and HRF. They also confirmed the cytokinergic activity of two of the human IgEs (Matsuda et al., 2005) and compared the cytokinergic activity of sera containing polyclonal IgE from AD patients and healthy controls in CBMC.

These experiments demonstrated that mouse HC but not PC IgEs, and the human monoclonal IgEs that exhibited cytokinergic activity in the earlier study, recognized one or more of the 

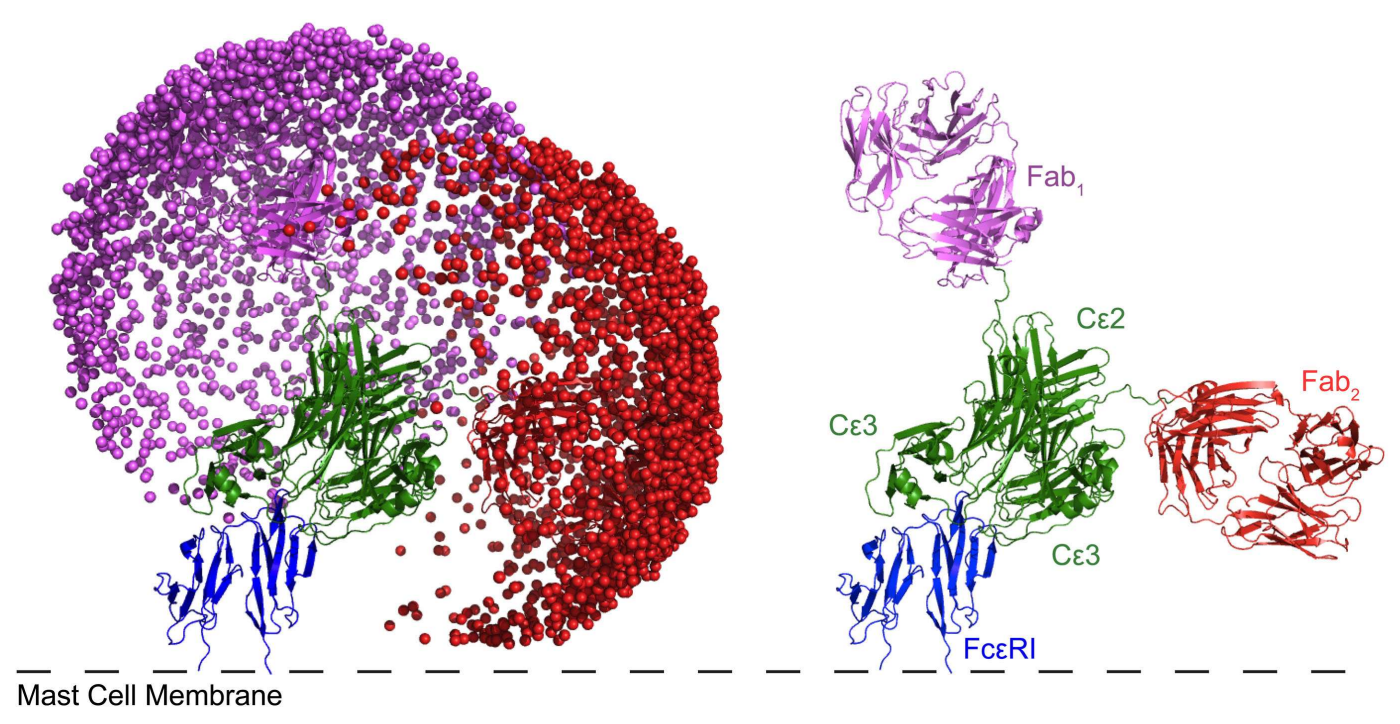

FIGURE 8 | Modeling of IgE bound to FceRI reveals that one of the Fabs predominately lies parallel to the membrane. Each sphere represents a possible position of the antigen binding site of the Fab. C $\varepsilon 4$ is present, but obscured by $\mathrm{C} \varepsilon 2$ and 3 . The modeled structure not only accounts for the observed restricted mobility of Fabs on IgE relative to IgG, but also suggests that two neighboring IgE-FceRI complexes are pre-disposed for ready cross-linking either by self-association or through a bridging protein. For more details of modeling see Hunt et al. (2012). autoantigens. Sera from AD patients but not the healthy controls showed increased reactivity against the single- and doublestranded DNA and $\beta$-galactosidase and increased levels of HRF. Sera from AD patients with DNA-reactive IgE induced more IL8 secretion from CBMC than sera from healthy controls. The individual HC IgEs bound to different subsets of these autoantigens, showing that there are multiple modes of IgE-FceRI selfassociation responsible for cytokinergic IgE activity, consistent with the heterogeneity of cytokinergic IgEs based on the strength of signal transduction (see Heterogeneity of IgEs). This is the result that would be expected if cytokinergic IgE activity arises from the random association of heavy- and light-chains after $\mathrm{VD}_{\mathrm{H}} \mathrm{J}$ recombination (cf. Wardemann et al., 2003), receptor editing, or receptor revision and switching to $\mathrm{IgE}$.

Many previous studies have revealed the existence of $\operatorname{IgE}$ autoantibodies (see Conformational Isomerism as a Basis of Cytokinergic Allergy?). Some of these are known to mediate mast cell activation in the classical manner with autoantigens (Valenta et al., 2009). The new insight offered by Kashiwakura et al. (2012b) is that there may be a cytokinergic element in IgE autoimmunity.

\section{POSSIBLE ORIGINS AND BIOLOGICAL SIGNIFICANCE OF CYTOKINERGIC IgE ACTIVITIES \\ GERMINAL CENTER REACTIONS AND THE LOCAL B CELL REPERTOIRE}

An alluring conjecture is that HC IgEs could be created de novo in the target organs of inflammation, caused by allergens or alternatively by non-allergic mechanisms, such as viral or bacterial infections. The resulting inflammatory cytokines may in turn induce polyclonal B cell proliferation and lymphoid neogenesis; i.e., the formation of tertiary lymphoid tissue, promoting germinal center reactions. The location of these events, determined by the cytokine environment, may specify the antibody class by directing class switching, e.g., to $\operatorname{IgG}$ in the synovial tissue in rheumatoid arthritis or $\operatorname{IgE}$ in the respiratory tract mucosa in rhinitis and asthma. Lymphoid neogenesis is well recognized in chronic autoimmune diseases, chronic infections, and B cell malignancies (Aloisi and Pujol-Borrell, 2006). It also occurs normally in the gastrointestinal tract, which is under constant bombardment from a complex and ever-changing mixture of bacterial products (Spencer et al., 2009). It has received less attention in relation to allergic disease, where $\operatorname{IgE}$ is the relevant antibody class, and to which we will confine our discussion.

By germinal center reactions we mean those that cause changes in the sequence of the expressed Ig genes in B cells secondary to the original $\mathrm{VD}_{\mathrm{H}} \mathrm{J}$ recombinatorial diversity created in bone marrow. This takes its name from the classical germinal centers located in secondary lymphoid tissue. The three germinal center reactions in B cells are somatic hypermutation, receptor revision, and class switch recombination. Somatic hypermutation introduces point mutations in the variable regions of the Ig heavy- and light-chains, which may either increase or decrease the affinity for an antigen and serves as the basis for affinity maturation in the immune response. In the mechanism of class switch recombination, the expressed variable region gene is recombined with one of the downstream constant region genes in the tandem array in the Ig heavy-chain locus on chromosome 14 and this diversifies the effector function and anatomical distribution of the antibody. Receptor revision is perhaps the most dramatic event, since it almost inevitably leads the $\mathrm{B}$ cell to lose its original antigen specificity or at least its affinity, but also offers a small chance of acquiring a new specificity against an environmental antigen. We suggest that randomization of the heavy- and light-chain combination in $\operatorname{IgE}$ is the origin of cytokinergic IgE (see Secondary Receptor Editing as a Source of Cytokinergic IgEs). 
There is ample evidence for the induction of tertiary lymphoid tissue and germinal center reactions in the respiratory tract in allergic disease. Local somatic hypermutation is revealed by the presence of clonal families in the nasal mucosa in rhinitis (Coker et al., 2003, 2005) and in the bronchial mucosa in asthma (Snow et al., 1995, 1997, 1998). Receptor revision is supported by the presence of RAG1 and RAG2 proteins in the tissue and the altered B cell repertoire (Coker et al., 2005). The abundance of Th2 and mast cells secreting IL-4, IL-13, and IL-6 provides an ideal environment for receptor revision and local class switching to IgE. Class switch recombination to $\operatorname{IgE}$ is experimentally observed by the presence of activation-induced cytidine deaminase in the tissue, along with $\varepsilon$ germline gene transcripts, $\varepsilon$ switch circle transcripts, $\varepsilon$-chain mRNA, and members of the same clonal family in IgE and IgA (Cameron et al., 2003; Coker et al., 2003; Takhar et al., 2005, 2007; Gould et al., 2006). The observed outcome is a massive increase in the proportion of IgE-expressing B cells (1/24), and of the plasma cells $(1 / 8)$ in the nasal mucosa in rhinitis, compared to $1 / 10,000$ of IgE-expressing B cells in the circulation (KleinJan et al., 2000). In atopic rhinitis allergen-specific IgE produced by $B$ cells in the nasal mucosa forms a substantial minority of the total RNA, and invariably a greater proportion than it represents in the circulation (Smurthwaite et al., 2001). We have estimated that the rate of $\operatorname{IgE}$ antibody synthesis in the nasal mucosa is 100 times greater than that required to saturate FceRI on mast cells in the tissue (Gould et al., 2003). Therefore the local IgE concentrations must be sufficient for cytokinergic activity. IgE in the circulation may simply be the spill over from respiratory tract and other tissue compartments (Gould et al., 2006; Eckl-Dorna et al., 2012).

Germinal center reactions are transient in secondary lymphoid tissue because they feed on the antigens that are eliminated in the immune response. Yet one cannot exclude the possibility that the target organs of allergic disease provide a survival niche for IgEexpressing B cells and plasma cells (Luger et al., 2009). In principle, this could be due in part to the cooperation between the B cells that continue to secrete IgE that binds to neighboring mast cells that respond to the IgE, according to the positive feedback mechanism illustrated in Figure 2. Persistent production of HC IgEs in the tissue may thus lead to the symptoms of chronic disease in the absence of allergen. Preliminary evidence showing the activity of cytokinergic IgEs produced by the randomization of $\varepsilon$ heavy- and light-chains in recombinant IgEs derived from the nasal mucosa of rhinitis patients (see Nature of the "Active Sites" in Cytokinergic $\operatorname{IgE}$ ) is fully consistent with this scenario.

In summary we suggest the following pathway via cytokinergic IgE to chronic disease:

Primary (viral, bacterial, allergic) inflammation in the target organs of allergy $\rightarrow$ somatic hypermutation, receptor revision, and class switching to $\operatorname{IgE} \rightarrow \operatorname{IgEs}$ with instability in $\mathrm{Fv}$ due to random combination of $\mathrm{V}_{\mathrm{H}}$ and $\mathrm{V}_{\mathrm{L}}$ sequences during receptor revision $\rightarrow$ polyspecific cytokinergic IgE $\rightarrow$ chronic disease.

What then might be the biological function of local receptor revision and the production of polyspecific cytokinergic IgE in the respiratory tract and gastrointestinal mucosa and skin? All these are barrier tissues involved in immune defense against multitudinous ever-changing external threats. It may be vital to maintain the diversity of the local antibody repertoire (Spencer et al., 2009), and this is surely an effective, but risky strategy.

\section{DIAGNOSIS AND THERAPY}

IgE is central to allergic disease but as we have indicated above IgEs are heterogeneous and similar symptoms are generated by different pathomechanisms. Cytokineric IgEs may be produced in an inflammatory response and may cause the symptoms of allergy in the absence of allergen. The non-anaphylactogenic antiIgE antibody, omalizumab, has proved to be a generally effective therapy in the clinic for moderate to severe asthma and in a wide variety of pre-clinical investigations on other allergic conditions. Since omalizumab acts by competing with FceRI for IgE binding it does not prevent IgE synthesis. Therefore, intensive efforts have been devoted to do this. For example, IgEs have been engineered to target the extra-membrane-proximal domain of $\operatorname{IgE}$ on B cells to induce cell death (Feichtner et al., 2008; Brightbill et al., 2010; Chen et al., 2010). The murine precursor of omalizumab has been re-engineered to increase its affinity for $\operatorname{IgE}$ and induce the co-ligation of membrane IgE and Fc $\gamma$ RIIb, which inhibits IgE synthesis, as well as neutralizing free IgE (Chu et al., 2012). It has been lamented recently that both anti-IgE therapies and the more commonly prescribed anti-inflammatory corticosteroids have actually been "too successful," in that they benefit patients with different underlying pathobiologies (Drazen, 2012). A better understanding of these pathobiologies would enable more specific diagnostic tests and targeted treatments.

We have attempted in this review to alert the reader to the different modes of IgE activity in the activation of mast cells and basophils. Inhibitors of oxidative stress (see Divergent Pathways of Signal Transduction) and of HRF binding to IgE (see A Different Kind of Cytokinergic Activity: Histamine-Releasing Factor) have been flagged up as potential therapies to intervene in the activity of cytokinergic IgE, but further research will undoubtedly uncover others.

\section{CONCLUSION AND UNANSWERED OUESTIONS}

We hope we may have persuaded the reader that cytokinergic activity is no mere academic curiosity, relevant only to model haptenspecific mouse antibodies acting on cultured mast cells, but that it is likely also to trouble humans. Most provocative perhaps may be the conjecture that these cytokinergic IgEs play a part in triggering and perpetuating the symptoms of allergic rhinitis and asthma. Therefore, this seems to us an area of no small topical interest.

If it be granted that cytokinergic activity is a real immunological phenomenon, then the immediate challenges in understanding its molecular basis are mainly structural, biochemical, and biophysical. The conjectural mechanisms we have outlined of the events that follow the binding of a cytokinergic IgE to the mast cell need to be tested. Detailed structural and dynamic studies have so far been confined to a single case (SPE-7 IgE), and need to be extended to other cytokinergic IgEs to establish the generality of the conclusions. Nor has anything yet been undertaken to relate the highly variable level of cytokinergic activity to amino acid sequence differences. Additional questions also arise: are differences in cytokinergic IgE potency linked to degree of conformational mutability? Are the structural and dynamic characteristics 
of the IgEs governed to any significant extent by the $\mathrm{V}_{\mathrm{H}}$ and $\mathrm{V}_{\mathrm{L}}$ pairings? Are the $\mathrm{V}_{\mathrm{H}}$ and $\mathrm{V}_{\mathrm{L}}$ sequences and pairings in IgE in the target organs of allergy unique to these sites, inasmuch as they are probably generated de novo by local germinal center reactions? What is the evolutionary advantage of cytokinergic IgEs? Considering their apparent place in the front-line of immune defense, do they perhaps perform an innate immune function, rather like the circulating IgM produced by naïve B cells? Do cytokinergic IgEs also pose a risk of engendering a "pseudo-allergy" and, if so, how might one intervene to promote or suppress their formation? The answers to many of these questions are well within the reach of present-day technology.

\section{REFERENCES}

Aalberse, R. C., Akkerdaas, J., and Van Ree, R. (2001). Cross-reactivity of IgE antibodies to allergens. Allergy $56,478-490$.

Abhinandan, K. R., and Martin, A. C. (2010). Analysis and prediction of VH/VL packing in antibodies. Protein Eng. Des. Sel. 23, 689-697.

Aloisi, F., and Pujol-Borrell, R. (2006). Lymphoid neogenesis in chronic inflammatory diseases. Nat. Rev. Immunol. 6, 205-217.

Asai, K., Kitaura, J., Kawakami, Y., Yamagata, N., Tsai, M., Carbone, D. P., Liu, F. T., Galli, S. J., and Kawakami, T. (2001). Regulation of mast cell survival by IgE. Immunity 14, 791-800.

Barthelemy, P. A., Raab, H., Appleton, B. A., Bond, C. J., Wu, P., Wiesmann, C., and Sidhu, S. S. (2008). Comprehensive analysis of the factors contributing to the stability and solubility of autonomous human $\mathrm{VH}$ domains. $J$. Biol. Chem. 283, 3639-3654.

Beeh, K. M., Ksoll, M., and Buhl, R. (2000). Elevation of total serum immunoglobulin $\mathrm{E}$ is associated with asthma in nonallergic individuals. Eur. Respir. J. 16, 609-614.

Bentley, G. A., Boulot, G., Riottot, M. M., and Poljak, R. J. (1990). Three-dimensional structure of an idiotope-anti-idiotope complex. Nature 348, 254-257.

Boehm, M. K., Corper, A. L., Wan, T., Sohi, M. K., Sutton, B. J., Thornton, J. D., Keep, P. A., Chester, K. A., Begent, R. H., and Perkins, S. J. (2000). Crystal structure of the anti(carcinoembryonic antigen) singlechain Fv antibody MFE-23 and a model for antigen binding based on intermolecular contacts. Biochem. J. 346(Pt 2), 519-528.

Brightbill, H. D., Jeet, S., Lin, Z., Yan, D., Zhou, M., Tan, M., Nguyen, A., Yeh, S., Delarosa, D., Leong, S. R., Wong, T., Chen, Y., Ultsch, M., Luis, E., Ramani, S. R., Jackman, J., Gonzalez, L., Dennis, M. S., Chuntharapai, A., Deforge, L., Meng, Y. G., Xu, M., Eigenbrot, C., Lee, W. P., Refino, C.
J., Balazs, M., and Wu, L. C. (2010). Antibodies specific for a segment of human membrane IgE deplete IgE-producing B cells in humanized mice. J. Clin. Invest. 120, 2218-2229.

Bryce, P. J., Miller, M. L., Miyajima, I., Tsai, M., Galli, S. J., and Oettgen, H. C. (2004). Immune sensitization in the skin is enhanced by antigenindependent effects of IgE. Immunity 20, 381-392.

Burrows, B., Martinez, F. D., Halonen, M., Barbee, R. A., and Cline, M. G. (1989). Association of asthma with serum IgE levels and skin-test reactivity to allergens. N. Engl. J. Med. 320, 271-277.

Calarese, D. A., Scanlan, C. N., Zwick, M. B., Deechongkit, S., Mimura, Y., Kunert, R., Zhu, P., Wormald, M. R., Stanfield, R. L., Roux, K. H., Kelly, J. W., Rudd, P. M., Dwek, R. A., Katinger, H., Burton, D. R., and Wilson, I. A. (2003). Antibody domain exchange is an immunological solution to carbohydrate cluster recognition. Science 300, 2065-2071.

Cameron, L., Gounni, A. S., Frenkiel, S., Lavigne, F., Vercelli, D., and Hamid, Q. (2003). S epsilon S mu and S epsilon $\mathrm{S}$ gamma switch circles in human nasal mucosa following ex vivo allergen challenge: evidence for direct as well as sequential class switch recombination. J. Immunol. 171, 3816-3822.

Caravella, J. A., Wang, D., Glaser, S. M., and Lugovskoy, A. (2010). Structure-guided design of antibodies. Curr. Comput. Aided Drug Des. 6, 128-138.

Charles, N., Monteiro, R. C., and Benhamou, M. (2004). p28, a novel IgE receptor-associated protein, is a sensor of receptor occupation by its ligand in mast cells. J. Biol. Chem. 279, 12312-12318.

Chatellier, J., Van Regenmortel, M. H., Vernet, T., and Altschuh, D. (1996). Functional mapping of conserved residues located at the $\mathrm{VL}$ and $\mathrm{VH}$ domain interface of a Fab. J. Mol. Biol. 264, 1-6.

\section{ACKNOWLEDGMENTS}

We are indebted to the following funding bodies for supporting our work referred to in the current publication: a Medical Research Council (UK) Ph.D. Studentship (Heather J. Bax); Medical Research Council (UK) Program Grant G1100090 (Anthony H. Keeble and Hannah J. Gould); and the Department of Health via the National Institute for Health Research (NIHR) comprehensive Biomedical Research Center award to Guy's and St. Thomas' NHS Foundation Trust in partnership with King's College London, and King's College Hospital NHS Foundation Trust (Hannah J. Gould). We would also like to thank Dr. Holly Bowen for help in designing the figures.

Chen, J. B., Wu, P. C., Hung, A. F., Chu, C. Y., Tsai, T. F., Yu, H. M., Chang, H. Y., and Chang, T. W. (2010). Unique epitopes on $\mathrm{C}$ epsilon $\mathrm{mX}$ in IgE-B cell receptors are potentially applicable for targeting IgE-committed B cells. J. Immunol. 184, 1748-1756.

Chu, S. Y., Horton, H. M., Pong, E. Leung, I. W., Chen, H., Nguyen, D. H., Bautista, C., Muchhal, U. S., Bernett, M. J., Moore, G. L., Szymkowski, D. E., and Desjarlais, J. R. (2012). Reduction of total IgE by targeted coengagement of IgE B-cell receptor and FcgammaRIIb with Fcengineered antibody. J. Allergy Clin. Immunol. 129, 1102-1115.

Chung, K. F., and Marwick, J. A. (2010). Molecular mechanisms of oxidative stress in airways and lungs with reference to asthma and chronic obstructive pulmonary disease. Ann. N. Y. Acad. Sci. 1203, 85-91.

Coker, H. A., Durham, S. R., and Gould, H. J. (2003). Local somatic hypermutation and class switch recombination in the nasal mucosa of allergic rhinitis patients. J. Immunol. 171, 5602-5610.

Coker, H. A., Harries, H. E., Banfield, G. K., Carr, V. A., Durham, S. R., Chevretton, E., Hobby, P., Sutton, B. J., and Gould, H. J. (2005). Biased use of VH5 IgE-positive B cells in the nasal mucosa in allergic rhinitis. $J$. Allergy Clin. Immunol. 116, 445-452.

Conrad, D. H., Wingard, J. R., and Ishizaka, T. (1983). The interaction of human and rodent IgE with the human basophil IgE receptor. J. Immunol. 130, 327-333.

Conroy, M. C., Adkinson, N. F. Jr., and Lichtenstein, L. M. (1977). Measurement of IgE on human basophils: relation to serum $\mathrm{IgE}$ and antiIgE-induced histamine release. J. Immunol. 118, 1317-1321.

Corper, A. L., Sohi, M. K., Bonagura, V. R., Steinitz, M., Jefferis, R., Feinstein, A., Beale, D., Taussig, M. J., and Sutton, B. J. (1997). Structure of human IgM rheumatoid factor Fab bound to its autoantigen IgG Fc reveals a novel topology of antibodyantigen interaction. Nat. Struct. Biol. 4, 374-381.

Cruse, G., Cockerill, S., and Bradding, P. (2008). IgE alone promotes human lung mast cell survival through the autocrine production of IL-6. BMC Immunol. 9, 2. doi:10.1186/14712172-9-2

Cruse, G., Kaur, D., Yang, W., Duffy, S. M., Brightling, C. E., and Bradding, P. (2005). Activation of human lung mast cells by monomeric immunoglobulin E. Eur. Respir. J. 25, 858-863.

DeLisi, C. (1981). The magnitude of signal amplification by ligandinduced receptor clustering. Nature 289, 322-323.

Drazen, J. M. (2012). Asthma: the paradox of heterogeneity. J. Allergy Clin. Immunol. 129, 1200-1201.

Eckl-Dorna, J., Pree, I., Reisinger, J., Marth, K., Chen, K.-W., Vrtala, S., Spitzauer, S., Valenta, R., and Niederberger, V. (2012). The majority of allergen-specific IgE in the blood of allergic patients does not originate from blood-derived B cells or plasma cells. Clin. Exp. Allergy. doi: 10.1111/j.1365-2222.2012.04030.x.

Ehrlich, P. (1900). Croonian lecture: on immunity with special reference to cell life. Proc. R. Soc. Lond. B Biol. Sci. 66, 424-448.

Eisenberg, R. A. (2012). Secondary receptor editing in the generation of autoimmunity. Autoimmun. Rev. doi: 10.1016/j.autrev.2012.02.004

Eshhar, Z., Ofarim, M., and Waks, T. (1980). Generation of hybridomas secreting murine reaginic antibodies of anti-DNP specificity. J. Immunol. 124, 775-780.

Feichtner, S., Infuhr, D., AchatzStraussberger, G., Schmid, D., Karnowski, A., Lamers, M., Rhyner, C., Crameri, R., and Achatz, G. (2008). Targeting the extracellular membrane-proximal domain of membrane-bound IgE by passive immunization blocks IgE synthesis in vivo. J. Immunol. 180, 5499-5505. 
Fewtrell, C., and Metzger, H. (1980). Larger oligomers of $\mathrm{IgE}$ are more effective than dimers in stimulating rat basophilic leukemia cells. $J$. Immunol. 125, 701-710.

Field, K. A., Holowka, D., and Baird, B. (1997). Compartmentalized activation of the high affinity immunoglobulin E receptor within membrane domains. J. Biol. Chem. 272, 4276-4280.

Foote, J., and Milstein, C. (1991). Kinetic maturation of an immune response. Nature 352, 530-532.

Foote, J., and Milstein, C. (1994). Conformational isomerism and the diversity of antibodies. Proc. Natl. Acad. Sci. U.S.A. 91, 10370-10374.

Furuichi, K., Rivera, J., and Isersky, C. (1985). The receptor for immunoglobulin $\mathrm{E}$ on rat basophilic leukemia cells: effect of ligand binding on receptor expression. Proc. Natl. Acad. Sci. U.S.A. 82, 1522-1525.

Galli, S. J., Grimbaldeston, M., and Tsai, M. (2008). Immunomodulatory mast cells: negative, as well as positive, regulators of immunity. Nat. Rev. Immunol. 8, 478-486.

Galli, S. J., Maurer, M., and Lantz, C. S. (1999). Mast cells as sentinels of innate immunity. Curr. Opin. Immunol. 11, 53-59.

Genovese, A., Rossi, F. W., Spadaro, G., Galdiero, M. R., and Marone, G. (2010). Human cardiac mast cells in anaphylaxis. Chem. Immunol. Allergy 95, 98-109.

Gilchrest, H., Cheewatrakoolpong, B., Billah, M., Egan, R. W., Anthes, J. C., and Greenfeder, S. (2003). Human cord blood-derived mast cells synthesize and release I-309 in response to IgE. Life Sci. 73, 2571-2581.

Gould, H. J., and Sutton, B. J. (2008). IgE in allergy and asthma today. Nat. Rev. Immunol. 8, 205-217.

Gould, H. J., Sutton, B. J., Beavil, A. J., Beavil, R. L., Mccloskey, N., Coker, H. A., Fear, D., and Smurthwaite, L. (2003). The biology of IgE and the basis of allergic disease. Аnпи. Rev. Immunol. 21, 579-628.

Gould, H. J., Takhar, P., Harries, H. E., Durham, S. R., and Corrigan, C. J. (2006). Germinal-centre reactions in allergic inflammation. Trends Immunol. 27, 446-452.

Harnett, W., and Harnett, M. M. (2010). Helminth-derived immunomodulators: can understanding the worm produce the pill? Nat. Rev. Immunol. $10,278-284$.

Hillion, S., Dueymes, M., Youinou, P., and Jamin, C. (2007a). IL-6 contributes to the expression of RAGs in human mature B cells. J. Immunol. 179, 6790-6798.

Hillion, S., Youinou, P., and Jamin, C. (2007b). Peripheral expression of RAG in human B lymphocytes in normal and pathological conditions is dependent on interleukin-6. Autoimmun. Rev. 6, 415-420.

Holdom, M. D., Davies, A. M., Nettleship, J. E., Bagby, S. C., Dhaliwal, B., Girardi, E., Hunt, J., Gould, H. J., Beavil, A. J., Mcdonnell, J. M., Owens, R. J., and Sutton, B. J. (2011). Conformational changes in IgE contribute to its uniquely slow dissociation rate from receptor FcvarepsilonRI. Nat. Struct. Mol. Biol. 18, 571-576.

Hsu, C., and MacGlashan, D. Jr. (1996). IgE antibody up-regulates high affinity IgE binding on murine bone marrow-derived mast cells. Immunol. Lett. 52, 129-134.

Huff, T. F., Uede, T., Iwata, M., and Ishizaka, K. (1983). Modulation of the biologic activities of IgE-binding factors. III. Switching of a $\mathrm{T}$ cell hybrid clone from the formation of IgE-suppressive factor to the formation of IgE-potentiating factor. $J$. Immunol. 131, 1090-1095.

Hunt, J., Keeble, A. H., Dale, R. E., Corbett, M. K., Beavil, R. L., Levitt, J., Swann, M. J., Suhling, K., AmeerBeg, S., Sutton, B. J., and Beavil, A. J. (2012). A fluorescent biosensor reveals conformational changes in human immunoglobulin E Fc: implications for mechanisms of receptor binding, inhibition, and allergen recognition. J. Biol. Chem. 287, 17459-17470.

Igawa, T., Tsunoda, H., Kikuchi, Y., Yoshida, M., Tanaka, M., Koga, A., Sekimori, Y., Orita, T., Aso, Y., Hattori, K., and Tsuchiya, M. (2010). VH/VL interface engineering to promote selective expression and inhibit conformational isomerization of thrombopoietin receptor agonist single-chain diabody. Protein Eng. Des. Sel. 23, 667-677.

James, L. C., Roversi, P., and Tawfik, D. S. (2003). Antibody multispecificity mediated by conformational diversity. Science 299, 1362-1367.

James, L. C., and Tawfik, D. S. (2003a). Conformational diversity and protein evolution - a 60year-old hypothesis revisited. Trends Biochem. Sci. 28, 361-368.

James, L. C., and Tawfik, D. S. (2003b). The specificity of crossreactivity: promiscuous antibody binding involves specific hydrogen bonds rather than nonspecific hydrophobic stickiness. Protein Sci. 12, 2183-2193.
James, L. C., and Tawfik, D. S. (2005). Structure and kinetics of a transient antibody binding intermediate reveal a kinetic discrimination mechanism in antigen recognition. Proc. Natl. Acad. Sci. U.S.A. 102 12730-12735.

Kalesnikoff, J., Huber, M., Lam, V., Damen, J. E., Zhang, J., Siraganian, R. P., and Krystal, G. (2001) Monomeric IgE stimulates signaling pathways in mast cells that lead to cytokine production and cell survival. Immunity 14, 801-811.

Kashiwakura, J., Kawakami, Y., Yuki, K., Zajonc, D. M., Hasegawa, S., Tomimori, Y., Caplan, B., Saito, H., Furue, M., Oettgen, H. C., Okayama, Y. and Kawakami, T. (2009). Polyclonal IgE induces mast cell survival and cytokine production. Allergol. Int $58,411-419$.

Kashiwakura, J., Otani, I. M., and Kawakami, T. (2011). Monomeric $\mathrm{IgE}$ and mast cell development, survival and function. Adv. Exp. Med. Biol. 716, 29-46.

Kashiwakura, J. C., Ando, T., Matsumoto, K., Kimura, M., Kitaura, J., Matho, M. H., Zajonc, D. M., Ozeki, T., Ra, C., Macdonald, S. M., Siraganian, R. P. Broide, D. H., Kawakami, Y., and Kawakami, T. (2012a). Histaminereleasing factor has a proinflammatory role in mouse models of asthma and allergy. J. Clin. Invest. 122, 218-228.

Kashiwakura, J. C., Okayama, Y., Furue, M., Kabashima, K., Shimada, S., Ra, C., Siraganian, R. P., Kawakami, Y., and Kawakami, T. (2012b). Most highly cytokinergic IgEs have polyreactivity to autoantigens. Allergy Asthma Immunol. Res. 4, e124.

Kawakami, T., and Galli, S. J. (2002). Regulation of mast-cell and basophil function and survival by IgE. Nat. Rev. Immunol. 2, 773-786.

Kawakami, T., and Kitaura, J. (2005). Mast cell survival and activation by $\operatorname{IgE}$ in the absence of antigen: a consideration of the biologic mechanisms and relevance. J. Immunol. 175, 4167-4173.

Kawakami, Y., Yumoto, K., and Kawakami, T. (2007). An improved mouse model of atopic dermatitis and suppression of skin lesions by an inhibitor of Tec family kinases. Allergol. Int. 56, 403-409.

Khan, T., and Salunke, D. M. (2012). Structural elucidation of the mechanistic basis of degeneracy in the primary humoral response. J. Immunol. 188, 1819-1827.

Kinet, J. P. (1999). The high-affinity IgE receptor ( $\mathrm{Fc}$ epsilon $\mathrm{RI})$ : from physiology to pathology. Annu. Rev. Immunol. 17, 931-972.

Kitamura, Y., and Ito, A. (2005). Mast cell-committed progenitors. Proc. Natl. Acad. Sci. U.S.A. 102, 11129-11130.

Kitaura, J., Eto, K., Kinoshita, T., Kawakami, Y., Leitges, M., Lowell, C. A., and Kawakami, T. (2005). Regulation of highly cytokinergic IgE-induced mast cell adhesion by Src, Syk, Tec, and protein kinase C family kinases. J. Immunol. 174, 4495-4504.

Kitaura, J., Song, J., Tsai, M., Asai, K. Maeda-Yamamoto, M., Mocsai, A., Kawakami, Y., Liu, F. T., Lowell, C. A., Barisas, B. G., Galli, S. J., and Kawakami, T. (2003). Evidence that IgE molecules mediate a spectrum of effects on mast cell survival and activation via aggregation of the FcepsilonRI. Proc. Natl. Acad. Sci. U.S.A. 100, 12911-12916.

Kitaura, J., Xiao, W., Maeda-Yamamoto, M., Kawakami, Y., Lowell, C. A., and Kawakami, T. (2004). Early divergence of Fc epsilon receptor I signals for receptor up-regulation and internalization from degranulation, cytokine production, and survival. $J$. Immunol. 173, 4317-4323.

KleinJan, A., Vinke, J. G., Severijnen, L. W., and Fokkens, W. J. (2000). Local production and detection of (specific) IgE in nasal B-cells and plasma cells of allergic rhinitis patients. Eur. Respir. J. 15, 491-497.

Kohno, M., Yamasaki, S., Tybulewicz, V. L., and Saito, T. (2005). Rapid and large amount of autocrine IL-3 production is responsible for mast cell survival by IgE in the absence of antigen. Blood 105, 2059-2065.

Lancet, D., and Pecht, I. (1976). Kinetic evidence for hapten-induced conformational transition in immunoglobin MOPC 460. Proc. Natl. Acad. Sci. U.S.A. 73, 3549-3553.

Lee, Y. C., Boehm, M. K., Chester, K. A., Begent, R. H., and Perkins, S. J. (2002). Reversible dimer formation and stability of the anti-tumor single-chain Fv antibody MFE-23 by neutron scattering, analytical ultracentrifugation, and NMR and FTIR spectroscopy. J. Mol. Biol. 320, 107-127.

Li, M., Gustchina, A., Alexandratos, J., Wlodawer, A., Wunschmann, S., Kepley, C. L., Chapman, M. D., and Pomes, A. (2008). Crystal structure of a dimerized cockroach allergen Bla g 2 complexed with a monoclonal antibody. J. Biol. Chem. 283, 22806-22814

Liu, F. T. (2005). Regulatory roles of galectins in the immune response. 
Int. Arch. Allergy Immunol. 136, 385-400.

Liu, F. T., Bohn, J. W., Ferry, E. L., Yamamoto, H., Molinaro, C. A., Sherman, L. A., Klinman, N. R., and Katz, D. H. (1980). Monoclonal dinitrophenyl-specific murine IgE antibody: preparation, isolation, and characterization. J. Immunol. 124, 2728-2737.

Lorentz, A., Wilke, M., Sellge, G., Worthmann, H., Klempnauer, J., Manns, M. P., and Bischoff, S. C. (2005). IL-4-induced priming of human intestinal mast cells for enhanced survival and Th2 cytokine generation is reversible and associated with increased activity of ERK $1 / 2$ and c-Fos. J. Immunol. 174, 6751-6756.

Luger, E. O., Fokuhl, V., Wegmann, M., Abram, M., Tillack, K., Achatz, G., Manz, R. A., Worm, M., Radbruch, A., and Renz, H. (2009). Induction of long-lived allergen-specific plasma cells by mucosal allergen challenge. $J$. Allergy Clin. Immunol. 124, 819-826, e814.

MacDonald, S. M. (1996). Histaminereleasing factors. Curr. Opin. Immunol. 8, 778-783.

MacDonald, S. M., Lichtenstein, L. M., Proud, D., Plaut, M., Naclerio, R. M., Macglashan, D. W., and Kagey-Sobotka, A. (1987). Studies of IgE-dependent histamine releasing factors: heterogeneity of IgE. J. Immunol. 139, 506-512.

MacDonald, S. M., Rafnar, T., Langdon, J., and Lichtenstein, L. M. (1995). Molecular identification of an IgE-dependent histaminereleasing factor. Science 269, 688-690.

MacGlashan, D. Jr. (2005). IgE and FcepsilonRI regulation. Clin. Rev. Allergy Immunol. 29, 49-60.

Manivel, V., Sahoo, N. C., Salunke, D. M., and Rao, K. V. (2000). Maturation of an antibody response is governed by modulations in flexibility of the antigen-combining site. Immunity 13, 611-620.

Matsuda, K., Piliponsky, A. M., Iikura, M., Nakae, S., Wang, E. W., Dutta, S. M., Kawakami, T., Tsai, M., and Galli, S. J. (2005). Monomeric IgE enhances human mast cell chemokine production: IL-4 augments and dexamethasone suppresses the response. J. Allergy Clin. Immunol. 116, 1357-1363.

Nakanishi, T., Tsumoto, K., Yokota, A., Kondo, H., and Kumagai, I. (2008). Critical contribution of VHVL interaction to reshaping of an antibody: the case of humanization of anti-lysozyme antibody, HyHEL10. Protein Sci. 17, 261-270.
Nemazee, D. (2006). Receptor editing in lymphocyte development and central tolerance. Nat. Rev. Immunol. 6, 728-740.

Niemi, M., Jylha, S., Laukkanen, M. L., Soderlund, H., Makinen-Kiljunen, S., Kallio, J. M., Hakulinen, N., Haahtela, T., Takkinen, K., and Rouvinen, J. (2007). Molecular interactions between a recombinant IgE antibody and the beta-lactoglobulin allergen. Structure 15, 1413-1421.

Nunomura, S., Gon, Y., Yoshimaru, T., Suzuki, Y., Nishimoto, H., Kawakami, T., and Ra, C. (2005). Role of the FcepsilonRI beta-chain ITAM as a signal regulator for mast cell activation with monomeric IgE. Int. Immunol. 17, 685-694.

Oka, T., Hori, M., Tanaka, A., Matsuda, H., Karaki, H., and Ozaki, H. (2004). IgE alone-induced actin assembly modifies calcium signaling and degranulation in RBL-2H3 mast cells. Am. J. Physiol. Cell Physiol. 286, C256-C263.

Oskeritzian, C. A., Zhao, W., Pozez, A. L., Cohen, N. M., Grimes, M., and Schwartz, L. B. (2004). Neutralizing endogenous IL-6 renders mast cells of the MCT type from lung, but not the MCTC type from skin and lung, susceptible to human recombinant IL-4-induced apoptosis. J. Immunol. 172, 593-600.

Paar, J. M., Harris, N. T., Holowka, D., and Baird, B. (2002). Bivalent ligands with rigid double-stranded DNA spacers reveal structural constraints on signaling by $\mathrm{Fc}$ epsilon RI. J. Immunol. 169, 856-864.

Palm, N. W., Rosenstein, R. K., and Medzhitov, R. (2012). Allergic host defences. Nature 484, 465-472.

Pandey, V., Mihara, S., Fensome-Green, A., Bolsover, S., and Cockcroft, S. (2004). Monomeric IgE stimulates NFAT translocation into the nucleus, a rise in cytosol $\mathrm{Ca} 2+$, degranulation, and membrane ruffling in the cultured rat basophilic leukemia$2 \mathrm{H} 3$ mast cell line. J. Immunol. 172, 4048-4058.

Peden, D. B. (2011). The role of oxidative stress and innate immunity in $\mathrm{O}(3)$ and endotoxin-induced human allergic airway disease. Immunol. Rev. 242, 91-105.

Raghunathan, G., Smart, J., Williams, J., and Almargo, J. C. (2012). Antigenbinding site anatomy and somatic mutations in antibodies that recognize different types of antigens. $J$. Mol. Recognit. 25, 103-113.

Rashid, T., and Ebringer, A. (2012). Autoimmunity in rheumatic diseases is induced by microbial infections via crossreactivity or molecular mimicry. Autoimmune Dis. 2012, 539282

Rini, J. M., Schulze-Gahmen, U., and Wilson, I. A. (1992). Structural evidence for induced fit as a mechanism for antibody-antigen recognition. Science 255, 959-965.

Sakurai, D., Yamasaki, S., Arase, K., Park, S. Y., Arase, H., Konno, A., and Saito, T. (2004). Fc epsilon RI gamma-ITAM is differentially required for mast cell function in vivo. J. Immunol. 172, 2374-2381.

Schmid-Grendelmeier, P., Fluckiger, S. Disch, R., Trautmann, A., Wuthrich, B., Blaser, K., Scheynius, A., and Crameri, R. (2005). IgE-mediated and $\mathrm{T}$ cell-mediated autoimmunity against manganese superoxide dismutase in atopic dermatitis. J. Allergy Clin. Immunol. 115, 1068-1075.

Schweitzer-Stenner, R., and Pecht, I. (2005). Death of a dogma or enforcing the artificial: monomeric IgE binding may initiate mast cell response by inducing its receptor aggregation. J. Immunol. 174 4461-4464.

Segal, D. M., Taurog, J. D., and Metzger, H. (1977). Dimeric immunoglobulin E serves as a unit signal for mast cell degranulation. Proc. Natl. Acad. Sci. U.S.A. 74, 2993-2997.

Sethi, D. K., Agarwal, A., Manivel, V., Rao, K. V., and Salunke, D. M. (2006). Differential epitope positioning within the germline antibody paratope enhances promiscuity in the primary immune response. Immunity 24, 429-438.

Sly, L. M., Kalesnikoff, J., Lam, V., Wong, D., Song, C., Omeis, S., Chan, K., Lee, C. W., Siraganian, R. P., Rivera, J., and Krystal, G. (2008). IgEinduced mast cell survival requires the prolonged generation of reactive oxygen species. J. Immunol. 181, 3850-3860.

Smurthwaite, L., Walker, S. N., Wilson, D. R., Birch, D. S., Merrett, T. G., Durham, S. R., and Gould, H. J. (2001). Persistent IgE synthesis in the nasal mucosa of hay fever patients. Eur. J. Immunol. 31, 3422-3431.

Snow, R. E., Chapman, C. J., Frew, A. J., Holgate, S. T., and Stevenson, F. K. (1995). Analysis of Ig VH region genes encoding $\operatorname{IgE}$ antibodies in splenic B lymphocytes of a patient with asthma. J. Immunol. 154, 5576-5581.

Snow, R. E., Chapman, C. J., Frew, A. J., Holgate, S. T., and Stevenson, F. K. (1997). Pattern of usage and somatic hypermutation in the $\mathrm{V}(\mathrm{H}) 5$ gene segments of a patient with asthma: implications for IgE. Eur. J. Immunol. 27, 162-170.

Snow, R. E., Chapman, C. J., Holgate, S. T., and Stevenson, F. K. (1998). Clonally related IgE and IgG4 transcripts in blood lymphocytes of patients with asthma reveal differing patterns of somatic mutation. Eur. J. Immunol. 28, 3354-3361.

Spencer, J., Barone, F., and DunnWalters, D. (2009). Generation of Immunoglobulin diversity in human gut-associated lymphoid tissue. Semin. Immunol. 21, 139-146.

Spitzauer, S., Schweiger, C., Sperr, W. R., Pandjaitan, B., Valent, P., Muhl, S., Ebner, C., Scheiner, O., Kraft, D., Rumpold, H., and Valenta, R. (1994). Molecular characterization of $\operatorname{dog}$ albumin as a cross-reactive allergen. J. Allergy Clin. Immunol. 93, 614-627.

Stallman, P. J., and Aalberse, R. C. (1977). Estimation of basophilbound IgE by quantitative immunofluorescence microscopy. Int. Arch. Allergy Appl. Immunol. 54, 9-18.

Stanfield, R. L., Takimoto-Kamimura, M., Rini, J. M., Profy, A. T., and Wilson, I. A. (1993). Major antigeninduced domain rearrangements in an antibody. Structure 1, 83-93.

Stevens, F. J., Chang, C. H., and Schiffer, M. (1988). Dual conformations of an immunoglobulin lightchain dimer: heterogeneity of antigen specificity and idiotope profile may result from multiple variabledomain interaction mechanisms. Proc. Natl. Acad. Sci. U.S.A. 85, 6895-6899.

Sunyer, J., Anto, J. M., Castellsague, J., Soriano, J. B., and Roca, J. (1996). Total serum IgE is associated with asthma independently of specific IgE levels. The Spanish Group of the European Study of Asthma. Eur. Respir. J. 9, 1880-1884.

Swindle, E. J., Coleman, J. W., Deleo, F. R., and Metcalfe, D. D. (2007). FcepsilonRI- and Fcgamma receptor-mediated production of reactive oxygen species by mast cells is lipoxygenase- and cyclooxygenase-dependent and NADPH oxidase-independent. $J$. Immunol. 179, 7059-7071.

Swindle, E. J., and Metcalfe, D. D. (2007). The role of reactive oxygen species and nitric oxide in mast celldependent inflammatory processes. Immunol. Rev. 217, 186-205.

Takhar, P., Corrigan, C. J., Smurthwaite, L., O’Connor, B. J., Durham, S. R., Lee, T. H., and Gould, H. J. (2007). Class switch recombination to $\mathrm{IgE}$ in the bronchial mucosa of atopic and nonatopic patients with asthma. 
J. Allergy Clin. Immunol. 119, 213-218.

Takhar, P., Smurthwaite, L., Coker, H. A., Fear, D. J., Banfield, G. K., Carr, V. A., Durham, S. R., and Gould, H. J. (2005). Allergen drives class switching to IgE in the nasal mucosa in allergic rhinitis. J. Immunol. 174, 5024-5032.

Teplyakov, A., Obmolova, G., Malia, T., and Gilliland, G. (2011). Antigen recognition by antibody $\mathrm{C} 836$ through adjustment of $\mathrm{V}(\mathrm{L}) / \mathrm{V}(\mathrm{H})$ packing. Acta Crystallogr. Sect. F Struct. Biol. Cryst. Commun. 67, 1165-1167.

Thielges, M. C., Zimmermann, J., Yu, W., Oda, M., and Romesberg, F. E. (2008). Exploring the energy landscape of antibody-antigen complexes: protein dynamics, flexibility, and molecular recognition. Biochemistry 47, 7237-7247.

Thorpe, I. F., and Brooks, C. L. III (2007). Molecular evolution of affinity and flexibility in the immune system. Proc. Natl. Acad. Sci. U.S.A. 104, 8821-8826.

Turner, H., and Kinet, J. P. (1999). Signalling through the high-affinity IgE receptor Fc epsilonRI. Nature 402, B24-B30.

Valenta, R., Duchene, M., Pettenburger, K., Sillaber, C., Valent, P., Bettelheim, P., Breitenbach, M., Rumpold, H., Kraft, D., and Scheiner, O. (1991). Identification of profilin as a novel pollen allergen; IgE autoreactivity in sensitized individuals. Science 253, 557-560.

Valenta, R., Mittermann, I., Werfel, T., Garn, H., and Renz, H. (2009). Linking allergy to autoimmune disease. Trends Immunol. 30, 109-116.

Vargas-Madrazo, E., and Paz-Garcia, E. (2003). An improved model of association for VH-VL immunoglobulin domains: asymmetries between $\mathrm{VH}$ and $\mathrm{VL}$ in the packing of some interface residues. J. Mol. Recognit. $16,113-120$.

Wan, T., Beavil, R. L., Fabiane, S. M., Beavil, A. J., Sohi, M. K., Keown, M., Young, R. J., Henry, A. J., Owens, R. J., Gould, H. J., and Sutton, B. J. (2002). The crystal structure of $\mathrm{IgE} \mathrm{Fc}$ reveals an asymmetrically bent conformation. Nat. Immunol. 3 , 681-686.

Wang, J., Cheng, X., Xiang, M. X., Alanne-Kinnunen, M., Wang, J. A., Chen, H., He, A., Sun, X., Lin, Y., Tang, T. T., Tu, X., Sjoberg, S., Sukhova, G. K., Liao, Y. H., Conrad, D. H., Yu, L., Kawakami, T., Kovanen, P. T., Libby, P., and Shi, G. P. (2011). IgE stimulates human and mouse arterial cell apoptosis and cytokine expression and promotes atherogenesis in Apoe-/- mice. J. Clin. Invest. 121, 3564-3577.

Wantke, F., Macglashan, D. W., Langdon, J. M., and Macdonald, S. M. (1999). The human recombinant histamine releasing factor: functional evidence that it does not bind to the IgE molecule. J. Allergy Clin. Immunol. 103, 642-648.

Wardemann, H., Yurasov, S., Schaefer, A., Young, J. W., Meffre, E., and Nussenzweig, M. C. (2003). Predominant autoantibody production by early human B cell precursors. Science 301, 1374-1377.

Wedemayer, G. J., Patten, P. A., Wang, L. H., Schultz, P. G., and Stevens, R. C. (1997). Structural insights into the evolution of an antibody combining site. Science 276, 1665-1669.

Xie, L., Schroeder, J. T., Langdon, J. M., Sora-Scott, R. S., Kawakami, T., and Macdonald, S. M. (2008). Human IgE+ and IgE- are not equivalent to mouse highly cytokinergic IgE. J. Allergy Clin. Immunol. 121, 1027-1033.

Yadav, S., Laue, T. M., Kalonia, D. S., and Shire, S. J. (2012). The influence of charge distribution on self- association and viscosity behavior of monoclonal antibody solutions. Mol. Pharm. 9, 791-802.

Yamaguchi, M., Lantz, C. S., Oettgen, H. C., Katona, I. M., Fleming, T. Miyajima, I., Kinet, J. P., and Galli, S. J. (1997). IgE enhances mouse mast cell $\mathrm{Fc}($ epsilon)RI expression in vitro and in vivo: evidence for a novel amplification mechanism in IgE-dependent reactions. J. Exp. Med. 185, 663-672.

Yamaguchi, M., Sayama, K., Yano, K., Lantz, C. S., Noben-Trauth, N., Ra, C., Costa, J. J., and Galli, S. J. (1999). IgE enhances $\mathrm{Fc}$ epsilon receptor I expression and IgE-dependent release of histamine and lipid mediators from human umbilical cord blood-derived mast cells: synergistic effect of IL-4 and IgE on human mast cell Fc epsilon receptor I expression and mediator release. J. Immunol. 162, 5455-5465.

Yamasaki, S., Ishikawa, E., Kohno, M., and Saito, T. (2004). The quantity and duration of FcRgamma signals determine mast cell degranulation and survival. Blood 103, 3093-3101.

Yamasaki, S., Ishikawa, E., Sakuma, M., Kanagawa, O., Cheng, A. M., Malissen, B., and Saito, T. (2007). LAT and NTAL mediate immunoglobulin E-induced sustained extracellular signal-regulated kinase activation critical for mast cell survival. Mol. Cell. Biol. 27, 4406-4415.

Yanagida, M., Fukamachi, H., Ohgami, K., Kuwaki, T., Ishii, H., Uzumaki, H., Amano, K., Tokiwa, T., Mitsui, H. Saito, H., Iikura, Y., Ishizaka, T., and Nakahata, T. (1995). Effects of Thelper 2-type cytokines, interleukin3 (IL-3), IL-4, IL-5, and IL-6 on the survival of cultured human mast cells. Blood 86, 3705-3714.

Yin, J., Beuscher, A. E. T., Andryski, S. E., Stevens, R. C., and Schultz, P. G.
(2003). Structural plasticity and the evolution of antibody affinity and specificity. J. Mol. Biol. 330, 651-656.

Zhang, N., Holtappels, G., Gevaert, P., Patou, J., Dhaliwal, B., Gould, H., and Bachert, C. (2011). Mucosal tissue polyclonal $\mathrm{IgE}$ is functional in response to allergen and SEB. Allergy 66, 141-148.

Zimmermann, J., Oakman, E. L., Thorpe, I. F., Shi, X., Abbyad, P., Brooks, C. L. III, Boxer, S. G., and Romesberg, F. E. (2006). Antibody evolution constrains conformational heterogeneity by tailoring protein dynamics. Proc. Natl. Acad. Sci. U.S.A. 103, 13722-13727.

Zimmermann, J., Romesberg, F. E., Brooks, C. L. III, and Thorpe, I. F. (2010). Molecular description of flexibility in an antibody combining site. J. Phys. Chem. B 114, 7359-7370.

Conflict of Interest Statement: The authors declare that the research was conducted in the absence of any commercial or financial relationships that could be construed as a potential conflict of interest.

Received: 12 March 2012; accepted: 14 July 2012; published online: 06 August 2012.

Citation: Bax HJ, Keeble AH and Gould HJ (2012) Cytokinergic IgE action in mast cell activation. Front. Immun. 3:229. doi: 10.3389/fimmu.2012.00229

This article was submitted to Frontiers in Inflammation, a specialty of Frontiers in Immunology.

Copyright (c) 2012 Bax, Keeble and Gould. This is an open-access article distributed under the terms of the Creative Commons Attribution License, which permits use, distribution and reproduction in other forums, provided the original authors and source are credited and subject to any copyright notices concerning any third-party graphics etc. 